\title{
Strategically estimated CapEx: wave energy converter costs breakdown and parameterisation
}

Ophélie Choupin ( $\nabla$ o.choupin@net.estia.fr)

Griffith University Griffith Sciences https://orcid.org/0000-0003-1818-463X

Michael Henriksen

Wavepiston

Amir Etemad-Shahidi

Griffith University Griffith Sciences

Rodger Tomlinson

Griffith Centre for Coastal Management

\section{Research}

Keywords: Wave energy converter (WEC), Wave Energy Farm (WEF), Capital expenditure (CapEx), Cost model, Cost breakdown and parameterisation, Techno-economic analysis

Posted Date: December 23rd, 2020

DOI: https://doi.org/10.21203/rs.3.rs-133554/v1

License: (c) (1) This work is licensed under a Creative Commons Attribution 4.0 International License. Read Full License 
3 Ophelie Choupin $^{1 *}$, Michael Henriksen ${ }^{2}$, Amir Etemad-Shahidi $^{1,3}$, and Rodger Tomlinson ${ }^{1}$

$4 \quad{ }^{1}$ School of Engineering and Built Environment, and Griffith Centre for Coastal Management, Griffith University, Gold Coast, QLD, Australia

6 ${ }^{2}$ Wavepiston, Helsingør, Denmark

7 ${ }^{3}$ School of Engineering, Edith Cowan University, WA, 6027, Australia

8 * Correspondence: o.choupin@ net.estia.fr (Ophelie Choupin)

9 Amir Etemad-Shahidi email : a.etemadshahidi@griffith.edu.au, Michael Henriksen email :

10 mh@wavepiston.dk, and Rodger Tomlison email : $\underline{\text { r.tomlinson@ @riffith.edu.au }}$ 


\section{AbSTRACT:}

12 In wave renewable energy, the Capital Expenditure (CapEx) is often a fixed number or

13 depends on a single variable (e.g. power or converter characteristic mass). Hence, it poorly

14 highlights the CapEx dependency on the Wave Energy Converter (WEC) and Wave Energy

15 Farm (WEF) design, which in turn depend on the site characteristics. As, most of CapEx

16 components are accessible by wave companies nowadays, this article introduces the new

17 generic CapEx method. This method is divided into three steps: (1) distinguishing WEC's

18 elements from the WEF's; (2) defining the parameters characterising the WECs, WEFs, and

19 site locations; and (3) estimating elements that affect WEC and WEF elements' cost and

20 translate them into factors using the parameters defined in step (2). The case study is based

21 on Wavepiston because of its advanced stage and the availability of its WEC information and

22 costs. The focus of this study is on the detailed application of step (1) and (2) to Wavepiston,

23 to estimate the Wavepiston WEC cost using step (3). This study also illustrates how to handle

24 complex and limited datasets of WEC configuration and site characteristics. Moreover, the

25 results from the CapEx method were validated by manual estimations from Wavepiston. It

26 was found for Wavepiston WEC, the site characteristics were the least affecting parameters

27 in comparison to the WEC configuration parameters. This study also applies another

28 parameterised cost calculation method based on the Froude law similitude as a simpler but

29 more rigid alternative, for the CapEx method. It was shown that with appropriate scaling

30 parameter, the Similitude method provided similar, although higher, estimations than the

31 CapEx method's within low ranges of WEC up-scaling. In high ranges of up-scaling, the

32 Similitude method overestimated Wavepiston WEC cost. 
33 Keywords: Wave energy converter (WEC) - Wave Energy Farm (WEF) - Capital

34 expenditure (CapEx) - Cost model - Cost breakdown and parameterisation - Techno35 economic analysis

\section{INTRODUCTION}

37 Renewable energy systems are increasingly employed in the challenge against climate

38 change [1,2]. The exploitation of marine renewable energies (such as tides, waves, and

39 offshore wind) is increasing, but wave energy is rarely considered [3] and often neglected

$40[4,5]$. The Levelised Cost of Energy (LCoE) is one of the most important metrics to compare

41 renewables [6]. The LCoE of Wave Energy Farm (WEF) is defined as the product of the

42 levelised cost of the WEF over its entire lifecycle by the levelised energy produced for the

43 same time period [7]. LCoE estimation is challenging for WEFs [8] and when estimated, it

44 results in higher values compared to those of other renewables [9].

45 The device harvesting the ocean wave energy is the Wave Energy Converter (WEC) [10].

46 WECs have very different designs [11] as opposed to other renewables. This is due

47 particularly to the complex resource wave climate system [12-14]. Therefore, pairing WEC

48 and wave climate based on proper cost estimation and power production is an everyday

49 challenge, and so is attracting investment in wave renewable energy. Pairing WEC and

50 location of installation requires the selection of the WEC configuration (specific size and

51 dimensions) [15]. Consequently, the WEC and location pairing also involves the calculation

52 of the energy production component (or Annual Energy Production, AEP) and cost over the

53 different WEC configurations. A large part of the research in wave renewables is dedicated 
54 to AEP $[13,16,17]$ and to its calculation [25]. Consequently, AEP is probably the most reliable metric of $\operatorname{LCoE}[18,19]$ to date, whereas the cost remains a source of uncertainty. The cost is composed of the operation and maintenance costs (or Operational Expenditure, OpEx) and the Capital Expenditure (CapEx) which gathers all the other costs of LCoE [20]. Due to a lack of experience in WEF trials and despite the broad literature, the estimations of the OpEx are hardly trustworthy [21-23]. In contrast, wave energy companies know precisely most of the costs related to the CapEx, and OpEx has occasionally been estimated as a percentage of the CapEx [16,24-27]. Consequently, the assessment of the cost part of LCoE can be reduced to the CapEx.

The goal of this research is to provide a systematic and comprehensive method for cost calculation adaptable to all WECs. The developed method enables automatic WEF cost, and thereby CapEx estimations for large dataset of WEC configurations and site characteristics. This work investigates the integration of WEC, WEF, and site characteristics directly in the cost calculations. This calculation method could eventually improve WEC configurationlocation pairing and selection. This pairing is often reduced to either an energy-based approach or to a small number of locations and WEC/WEF designs as:

a. The manual cost estimation of large WEC configuration-location databases is time1 demanding.

b. CapEx is often defined for a fixed design of WEC and WEF by first distinguishing 3 the CapEx from the costs that belong to the wave farm, and second by providing a 4 breakdown of CapEx into its main components [16,28]. LaBonte et al. [29] also 
provided a clear decomposition of the CapEx. Their method is implemented within the National Renewable Energy Laboratory (NREL) System Advisor Model (SAM) tool [30] strongly linked to the study of Neary et al. [31] on the Reference Model Projects (RMP). Similarly, Chozas et al. [26] developed a Cost of Energy (COE) calculation tool. However, in these cases no process is developed to calculate the costs for large dataset of WEC configuration. In addition, site characteristics are considered in the sense that site, WEF, or WEC characteristic can only be changed one at a time; these methods and programs cannot be used to compare the costs for large databases. c. Chang et al. [8] amongst others [20,32,33], have estimated the cost for most of the devices investigated by Barbarit et al. [34]. Furthermore, specific costs have also been provided for CorPower Ocean [35,36], Pelamis and Wavestar [37], Wavedragon [38], Floating Power Plant A/S [39], M4 [40], and Seabased Industry AB [41], to name a few. These studies mainly used selected economic indicator-based equations such as the LCoE. Despite providing detailed costs, they did not offer clear methodologies to calculate these expenses.

d. Since the number of governing parameters affecting the costs is large $[8,28]$, studies often focus on a particular aspect of CapEx such as the mooring costs [42], or cable expenses to link the WEF to the grid $[9,28,43-45]$. These studies sometimes highlights the impact of parameters such as site characteristics, or wave and weather conditions on the diverse component and their costs. Yet, they do not provide calculation methods, and a single and synthetic methodology is not available. 
e. CapEx is sometimes provided as a single number depending on the power production capacity of the WEF [8,46-48]. This number multiplied by the WEF rated power provides the CapEx in euros. However, this global approach provides a rough average of the final CapEx and lacks understanding and control on the calculation of the costs within CapEx.

f. WEF elements cost such as the WEC and moorings, have also been parameterised using a single number depending on the WEC, or the WEC element, weight or characteristic mass [26]. For example, de Andres et al. [16] used the cost of steel from Myhr et al. [49] and they multiplied it by the WEC weight to estimate the WEC cost. However, steel prices are quite variable [49] so the cost estimation based on this approach remains approximate. Moreover, WECs are often composed of many different elements of various materials. Furthermore, WECs' dimensions are required to obtain the volume and so the mass of steel of the WEC, while they are rarely available. In some cases, the volume may need to be approximated due to complex shapes or multi-component design of the WEC. To sum up, this method can only be applied to a couple of elements from the WEF enabling only a partial flexibility of the CapEx calculations.

g. For a given WEC, de Andres et al. [35] provided a method (also applied by Pascal et al. [15]) scaling the CapEx with references to the Froude law similitude [50] used initially to scale marine structures in different sizes. In their study, de Andres et al. [35] adapted the Froude law for its application to CapEx. Yet, this approach remains global and lacks specific control in the calculation of the cost composing CapEx. 
118 This work provides a comprehensive but concise synthesis of the guidelines for WEC and

119 WEF cost breakdown and estimation. Moreover, these calculation methods are often

120 approximate and lack flexibility to integrate the many characteristics of WEC and site, in the

121 cost calculation. Subsequently, this study introduces the new generic "CapEx method" for

122 WECs, which is based on the aforementioned synthesis of previous guidelines and methods.

123 The aim is to develop a systematic techno-economic approach for CapEx and more

124 importantly the CapEx sub-cost calculations for large databases of WEF/WEC configurations

125 and site characteristics. This calculation method is compared with that of de Andres et al.

126 [35], which is referred to as the "Similitude method" in the rest of the study.

127 The absence of information to obtain CapEx is partially driven by confidentiality matters

128 relating to most companies. This study investigates Wavepiston [51] firstly, because the

129 company provided the access to its WEC structural and economic details. Secondly, its 1:2

130 scale prototype has been tested in Denmark at Hanstholm test site [52] and it is planned to

131 carry out full-scale testing at PLOCAN (Canary Islands - Spain) by the end of 2022 for

132 possible farm installation to supply a desalinisation plant in the North of Gran Canaria [53].

133 In Section 2 the CapEx and Similitude methods are fully described. Section 3 shows the

134 application of the two method to the complex database of Wavepiston WEC configurations.

135 Section 4 conducts the comparison and discussion between the CapEx and Similitude method

136 for Wavepiston, which also includes the analysis of the effect of the different WEC

137 configuration and site characteristic parameters, before concluding in Section 5. 


\section{Method}

139

\subsection{CAPEX METHOD}

140 This section describes the CapEx method, which is organised into three steps. It is worth

141 noting that since this research is dedicated to wave renewables, the description of the method

142 is associated with WEC and WEF examples, yet, the CapEx method can also be applied to

143 other renewables.

\subsubsection{Step 1: Elements and costs distinction}

145 The overall costs of a WEF project can be split into three parts:

146 1. Development cost gathers all expenses from the WEC concept to WEF final design for a particular location. It includes the costs for the WEC development through all the phases of the WEC lifecycle, as well as the pre-installation costs from Clark et al. demand infrastructures are also added.

These three aspects will then help in selecting the most appropriate WEF design for the location of interest, which includes decision on the number of WECs and the WEC configuration [20,33,36,38,39,54], the location of installation [46,55-57], the WEF arrangement, particularly regarding park effects and wave direction impact [56], and the selection of cables, moorings, and anchors $[9,42,45]$. 
2. Construction and installation costs of the WEF for each location. It accounts for the price to purchase and/or manufacture the WEF elements, deploy, install, and connect the WEF to the grid $[43,58]$ following the decisions of the WEF design mentioned in part 1.

3. Decommissioning costs is the budget allocated to WEF disconnection, uninstalling, and decommissioning. Often the disconnection and uninstall are included in the decommissioning. Clark et al. [28] broke down the decommissioning cost.

WEF project costs also occur during its lifetime such as insurances, taxes, rent of the location, amongst others [41,59], but it is less substantial. CapEx can be seen as the estimation of the costs of the beginning and the end of the WEF lifetime, while the operations and maintenance costs are spent during the WEF lifetime until the moment it is decommissioned [60]. CapEx usually gathers points 2 and 3, and occasionally the aforementioned additional costs, whereas the operation and maintenance cost often includes location rent and associated insurances [23]. It is worth noting that the LCoE calculation is linked to a specific farm project, and the cost of development might be spread over many projects, explaining the possible disregard of point 1 within CapEx.

The first step of the CapEx method is to transform the complex WEF system into simple elements that are easier to assess economically. This task also involves the WEC design breakdown [61]. This transformation consists of: (1) clearly defining the above different costs that will be considered in the CapEx; and (2) determining which component belongs to the WEC itself and which belongs to the WEF. Then each major element of the WEC and WEF 
178

179 181 includes the disconnection and uninstallation.

182 sorted between the WEC and WEF, their base or default cost can be estimated. This base cost

can be divided into sub-elements. Moreover, similar to the tidal farms [58], each component and sub-component may be associated with the following tasks: costs of manufacturing, assembly (onshore or offshore), deployment, installation, connection, and decommission that

The first four tasks happen at the beginning of the WEF lifetime, and last one at the end. Additionally, tasks may be associated with sub-tasks, and so in the following, both components and tasks are called elements and sub-components and sub-tasks sub-elements.

The level of detail of element and sub-element analysis is in line with the user knowledge accumulated about WEC and WEF design. This level of experience and knowledge can be measured using the Technology Readiness Levels (TRL) [62,63] or the WEC company phase [64].

\subsubsection{Step 2: Parameter selection}

The second step of the CapEx method is the selection of the parameters for the cost parameterisation. Each WEC is characterised by significant dimensions (e.g. WEC width and length, and number of energy-collectors if more than one) that are part of parameters. The sites' wave climates and particular characteristics, as well as additional features from the WEC, should be translated into parameters that may be required for the parameterisation.

\subsubsection{Step 3: Cost estimation and parameterisation}

The last step of the CapEx method is the cost parameterisation. Once elements and tasks are is obtained for WEC-WEF simplest and smallest conceivable design for commercialisation. 
199 The total cost of an element is composed of a base cost, and the margin the WEC company 200 expects to profit from selling this piece. Hence, each WEF and WEC element total cost is as 201 follows:

$$
\text { Element Total Cost }=\text { Element Base Cost }(1+\text { Element Margin 0.01 })
$$

202 The margin is in percentage, and the base and total costs in $€$. For WEF projects under TRL5, 203 companies may not consider the margin since it requires a certain experience to be estimated. 204 If the margins were neglected, then, Total Cost would equal Base Cost. It is worth noting that 205 the base cost may fundamentally be dependent on a specific variable; for example, the cost 206 of underwater cables is often provided in $€ / \mathrm{m}$. In such a case, the base cost may be divided 207 into two components with a fixed part and a part multiplied by the considered variable value, 208 in this example, the distance to shore.

209 In the CapEx method, at the level of the CapEx or WEC/WEF main elements, the base costs 210 are large being the sum of the total costs of the sub-elements, similar to the cost calculation 211 shown by Clark et al. [28]. In contrast, at the level of sub-element total cost, the base cost, in 212 this method, is the cost estimated for the smallest conceivable; but for marketable, size of the 213 device. The value of the sub-element base costs can often be determined from subcontractors' 214 catalogues and quotes.

215 A new cost in each element total cost function called factors can be introduced as:

$$
\text { Element Total Cost }=(\text { Element Base Cost }+ \text { Element Total Factor })(1+0.01 \text { Element Margin }),
$$


216 These factors try to capture future WEF local environmental, legislative, and economic

217 phenomenon. Depending on the reasoning of the company, the factors may be assessed in

218 different ways. The objective is to provide the initial description of how to obtain the final

219 estimation of each element for the considered parameterised WEF/WEC problem. The

220 factors can be used in five different ways, from the simplest (first parameterisation of the

221 costs), to the expert approaches through the intermediary and advanced levels; with

222 increasing flexibility and thereby complexity.

\section{2.1.3.1 Simplest approach for the factors and first parameterisation}

224 The simplest approach of the factors is dedicated to companies with a small TRL. In the

225 simplest approach each element's total factor would be a single number estimated from the

226 user's experience according to the element configuration or size and the characteristics of the

227 site. For instance, sites with challenging weather and high wave conditions require costlier

228 factors than for calmer sites.

229 The first parameterisation method consists of a single factor that is the total factor. The factor

230 is the multiplication of a parameter by a weight that illustrates the impact of this parameter

231 on the cost. The weight may be in the order of the base cost so that the associated factor

232 (multiplication of the weight and parameter) could be translated as a percentage of the base 233 cost.

\section{2.1.3.2 Intermediary and advanced parameterisation}

235 Assuming that the company is gaining more experience with WEF costs, the factors may take

236 the form of a sum of $n f$ parameters, amongst those selected in step 2, multiplied by a weight 
237 that would reflect the impact of the parameter on the overall cost enabling the

238 parameterisation process:

$$
\text { Total factor }=\sum_{i=1}^{n f} \text { Weight }_{\mathrm{i}} \text { Parameter }_{\mathrm{i}}
$$

239 The total factor is composed of several factors. Each factor is associated with a specific

240 phenomenon impact on the cost such that the factor parameter is the direct translation of the

241 phenomenon impact and the weight the strength of this phenomenon. Phenomena can be

242 scaling, site location, alongside weather and wave-climate conditions, amongst others. It is

243 worth mentioning that when examining the phenomenon affecting each WEC and WEF

244 element and sub-element costs, the list of parameters determined in step 2 might be extended

245 when there is no parameter representative enough of the phenomena.

246 Following Clark et al. [28] who decomposed the costs of a fixed hybrid offshore wind-wave

247 farm (or from Segura et al. [58] for tidal farms), the CapEx calculation can be parameterised

248 by: (a) determining all the phenomena affecting each cost; (b) translating these phenomena 249 into factors composed of the representative parameter multiplied by the weight of the 250 phenomenon on the considered cost; and (c) adding to each cost the sum of the resulting 251 factors. The intermediary approach of the factors is the implementation of more physical and 252 concrete phenomenon including scaling based on the WEC and WEF sizes, site 253 characteristics as the distance to shore amongst others, and local or regional (example of the 254 labour price) impacts on the costs. 
255 In the advanced approach, more abstract phenomena, such as economies of scale, power 256 absorption, and weather and wave climate effect on the costs could be translated into factors 257 that could be based on parameters such as the wave significant height, or wind speed.

\subsubsection{Expert approach of the factors}

259 A more experienced company could consider more complex weight factors as functions of

260 other parameters by using learning curve effects often encapsulating the economies of scale

$261[25,65,66]$, amongst others. Such improvement could similarly be made for the weather term,

262 as well as the other factors in general.

\subsection{SIMILITUDE METHOD}

264 The Similitude method from de Andres et al. [35] uses the Froude law similitude principles 265 [50] to scale the CapEx. Using the example of the CapEx calculation from Clark et al. [28], from

266 Segura et al. [58], or any other cost calculation, the Similitude method consists of:

a. Determine the source-dependency of the functionality of the modules associated with the costs. Table 1 provides a list of different dimension (also referred to as dimension, quantity, or sources), and their scaling parameter from the Froude law similitude (Sheng et al. [50] and Hughes [67] provided more sources).

b. Average all the scaling parameters to obtain the "weighted scale coefficient" shown in Equation (4), and as the CapEx $x_{\text {Base cost }}$ in Equation (4) and be multiplied by the new scale of the farm power the weighted scale coefficient following Equation (4). 


$$
\text { CapEx } \mathrm{x}_{\text {Total cost }}=\mathrm{CapEx}_{\text {Base cost }} \text { Scale }^{\text {Weighted scale coefficient }} \text {, }
$$

\begin{tabular}{cc}
\hline Function dimension & Scale parameter \\
\hline Acceleration & 0 \\
Area & 2 \\
Force & 3 \\
Length & 1 \\
Mass/Volume & 3 \\
Power & 3.5 \\
Pressure & 1 \\
Dimensionless quantity (such as efficiency) & 0 \\
Volume flow rate & 2.5 \\
\hline
\end{tabular}

\section{APPLiCATION TO WAVEPISTON WAVE EnERgy CONVERTER}

288 Since one of the objectives of this work is to illustrate an example on how to handle complex 289 and limited databases of WEC configurations and site characteristics, the factorisation level 
290 of this study is intermediate to emphasise on the description of the dataset. The CapEx

291 method and then the Similitude method are applied to Wavepiston.

\subsubsection{Step 1: Wavepiston WEC breakdown into elements}

294 Figure $1^{1}$ shows the Wavepiston WEC, often simply called Wavepiston, and its sub295 elements.

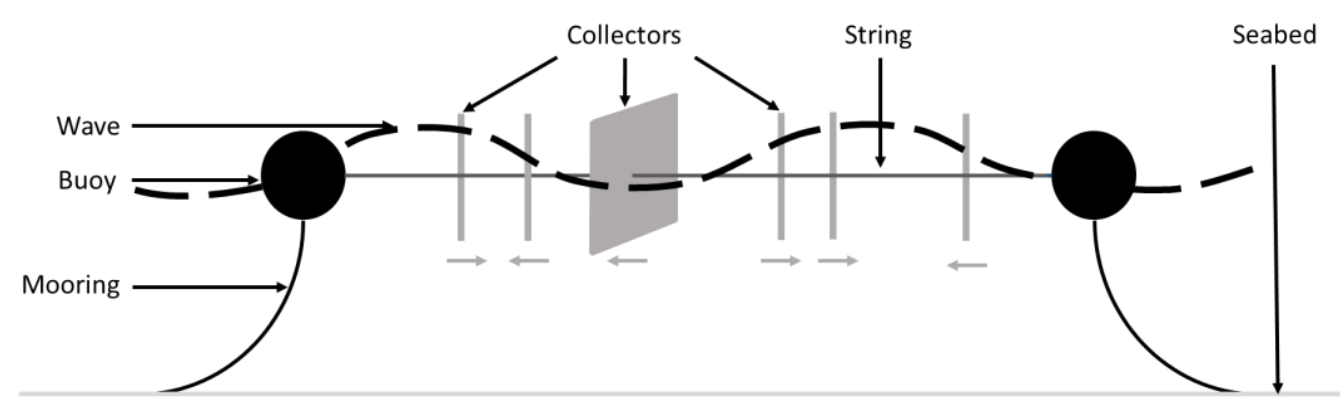

Figure 1. Wavepiston visual description

298 The WEC is a string of hinged energy collectors with the ability to move back and forth in a

299 limited space along the string. The string is attached to two buoys that are anchored to the 300 seabed (Figure 1).

\subsubsection{Collector}

302 The collectors are Wavepiston's PTOs illustrated in Figure 2. They are made of a plate that moves using a wagon (not shown in Figure 2) along a beam. This movement actions two

\footnotetext{
1 Wavepiston is currently developing a new version of their WEC without the string but this is still at the level of concept and is not yet computed neither tested so cannot be updated in the present.
} 
305 the string through the valves and the pipe.
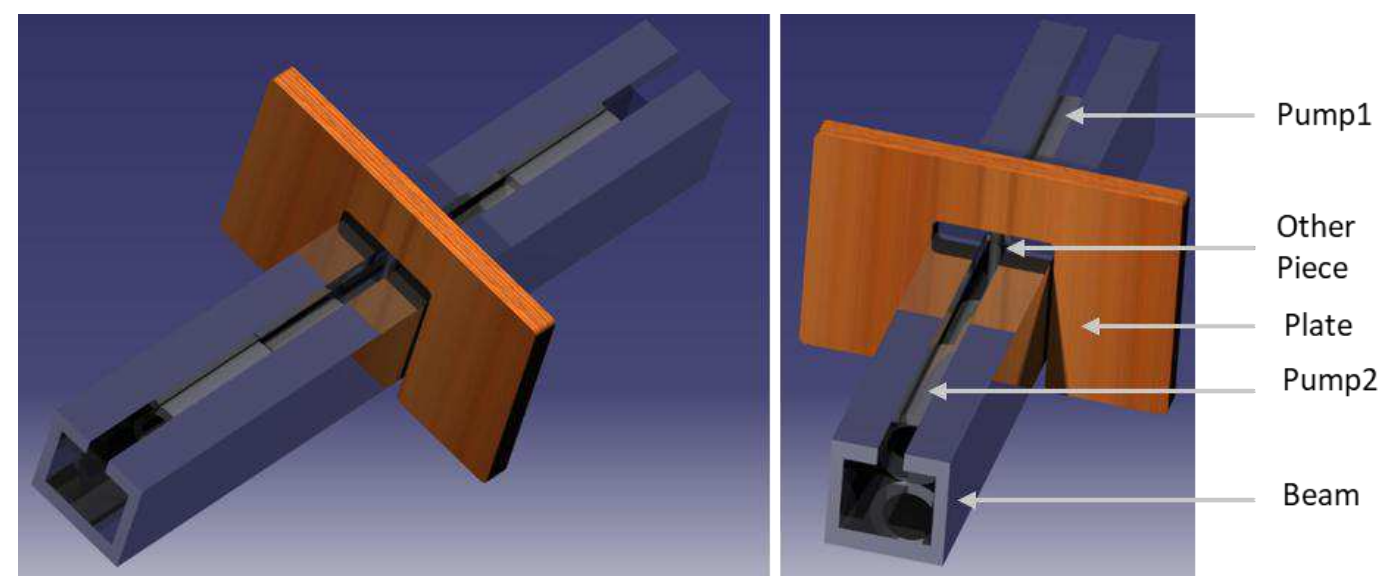

Figure 2. Collector artistic representation

The pipes and valves are part of the "other pieces" in Figure 2, which also include bolts,

309 joints, to name a few. Additional manufacturing is considered for the assembly of the 310 collector.

\subsubsection{String and moorings}

312 The string accounts for the two buoys and attached moorings including the anchors. The

313 string is made of wire and rope alongside a pipe joined to the collectors using connectors,

314 and valves. The pipe transmits the flux of water that will be used eventually to spin the turbine

315 of the generator. Additionally, the string needs shackles and connectors to attach the

316 collectors, buoys, and moorings. Furthermore, the string's elements gather the monitoring

317 and control systems.

318 The moorings were distinguished as a sub-element of the string since filling a very particular

319 purpose of holding the string. They are made of rope, chain, and wire alongside the use of

320 shackles. As well as for the collector, additional pieces (risers, fasteners, amongst others) are 
321 included in the string's elements that encapsulate both the additional pieces of the moorings

322 and the string.

\section{3.1.1.3 Summary and tasks}

324 Figure 3 illustrates the division of a Wavepiston WEC into elements and tasks such that all

325 pieces combined are sub-elements or tasks of the right column element to which they are

326 linked.

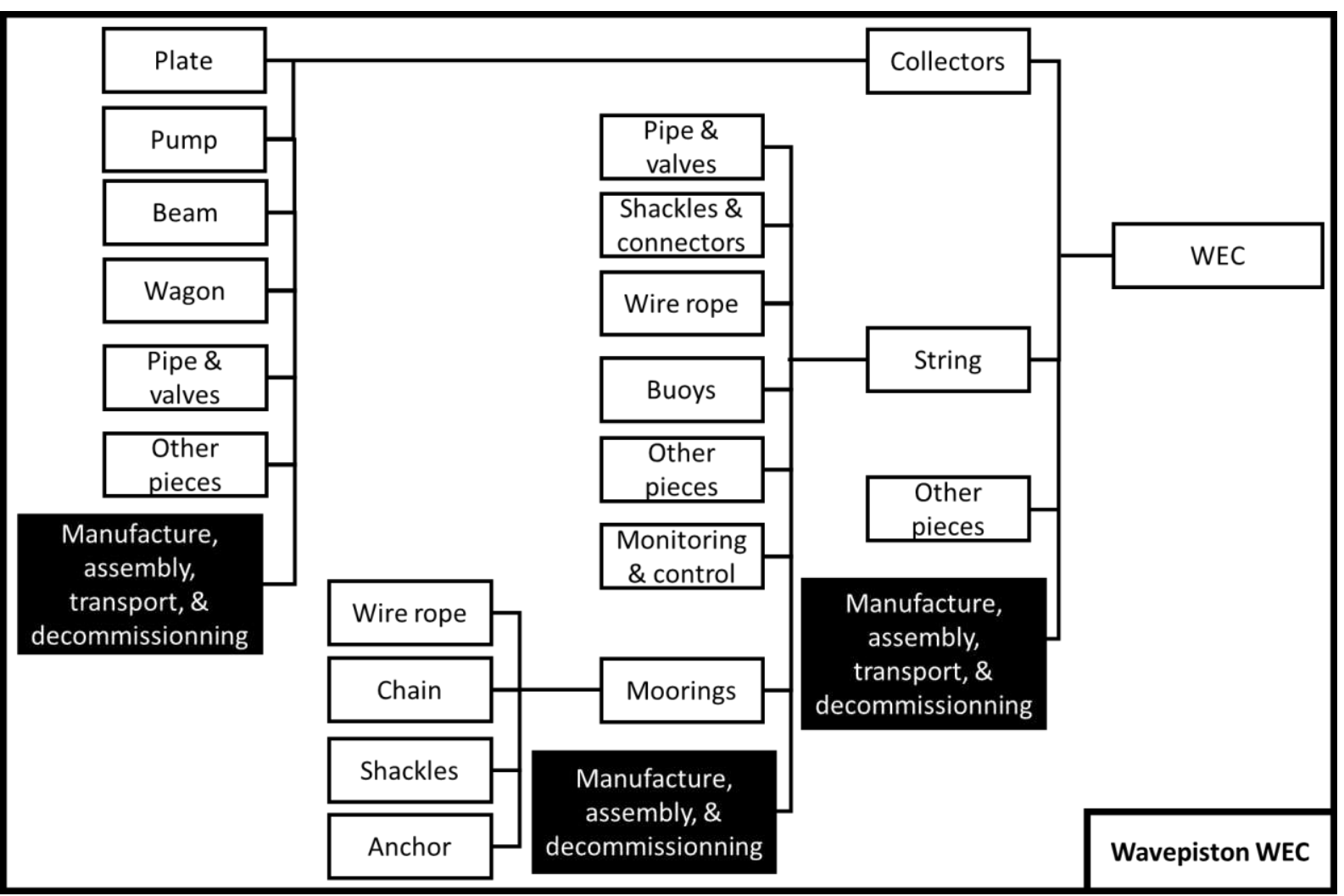

328 Figure 3. Wavepiston WEC main pieces and components (white cells) and tasks (dark cells) 329 gathering tasks.

330 Wavepiston manufacturing (Figure 3) cost is estimated as the sum of the $N p$ collectors,

331 including their attachment to the string. The transport task implies the use of boats to bring

332 to shore either a Wavepiston or just a collector from it. Hence, the transport does not appear

333 in the task box of the string sub-elements. Furthermore, the mooring elements possess no 
334 tasks because string elements integrate moorings, thence the actions apply the entire

335 moorings and not its pieces individually. Tasks including deployment connection and

336 disconnection alongside elements such as connecting cables to onshore power stations, as

337 well as turbines and generators belong to the WEF hence are not considered here.

\subsubsection{Step 2: Wavepiston WEC and site parameters}

339 The parameters that determine a Wavepiston WEC configuration are: the plate shape, ps (--

340 ), and its dimensions: plate area, $p a\left(\mathrm{~m}^{2}\right)$, plate width, $p w(\mathrm{~m})$, and depth, $p d(\mathrm{~m})$; as well as

341 the number of plates (and thereby collectors) per string, $N p(--)$, and the distance between the

342 plates called plate-location configuration, plc (m). This study also includes the water depth

343 at site, $s$, the wamit water depth, $h$, which is a parameter of the WEC configuration, and the

344 site water depth, $d$, which is the expected water depth where the farm is installed, and the 345 distance to the coastline, $q(\mathrm{~m})$.

346 The parameters used for the WEC model are $N p, p l c, p s, p w, p d$, and $h$. They are mentioned

347 in the following as the Wavepiston WEC configuration parameters and are the only "internal"

348 parameters defining each WEC configuration. Table 2 display their values and combinations.

349 Table 2 also shows that there are 184 combinations of the $N p, p l c, p s, p w, p d$, and $h$

350 parameters, for 53 configurations excluding $h$. The elliptical plates contain only diameters of

$351 p w=p d=3 \mathrm{~m}$ and $p w=p d=6.7 \mathrm{~m}$, which makes them in fact circular. The biggest circular plate

352 is assessed by the four $h$ scenarios, whereas the first is only evaluated for $h>>100 \mathrm{~m}$. The

353 rectangular equivalent exists only for $p s=p d=3 \mathrm{~m}$. Most of the combinations of $N p, p l c, p w$,

354 and $p d$ parameters for rectangular plates are provided for $h=20 \mathrm{~m}$. The smallest plates below 
$3554.5 \mathrm{~m}^{2}$ are only assessed as rectangular plates, for $p l c=0,13.5,16 \mathrm{~m}$, and for the extreme $356 h>>100 \mathrm{~m}$ or $h=20 \mathrm{~m}$. Finally, most of the plates above $6 \mathrm{~m}^{2}$ are assessed by all the 357 combinations of $N p-p l c$.

358 Table 2. Distribution of the wamit water depth, h, for the Wavepiston WEC configuration 359 parameters

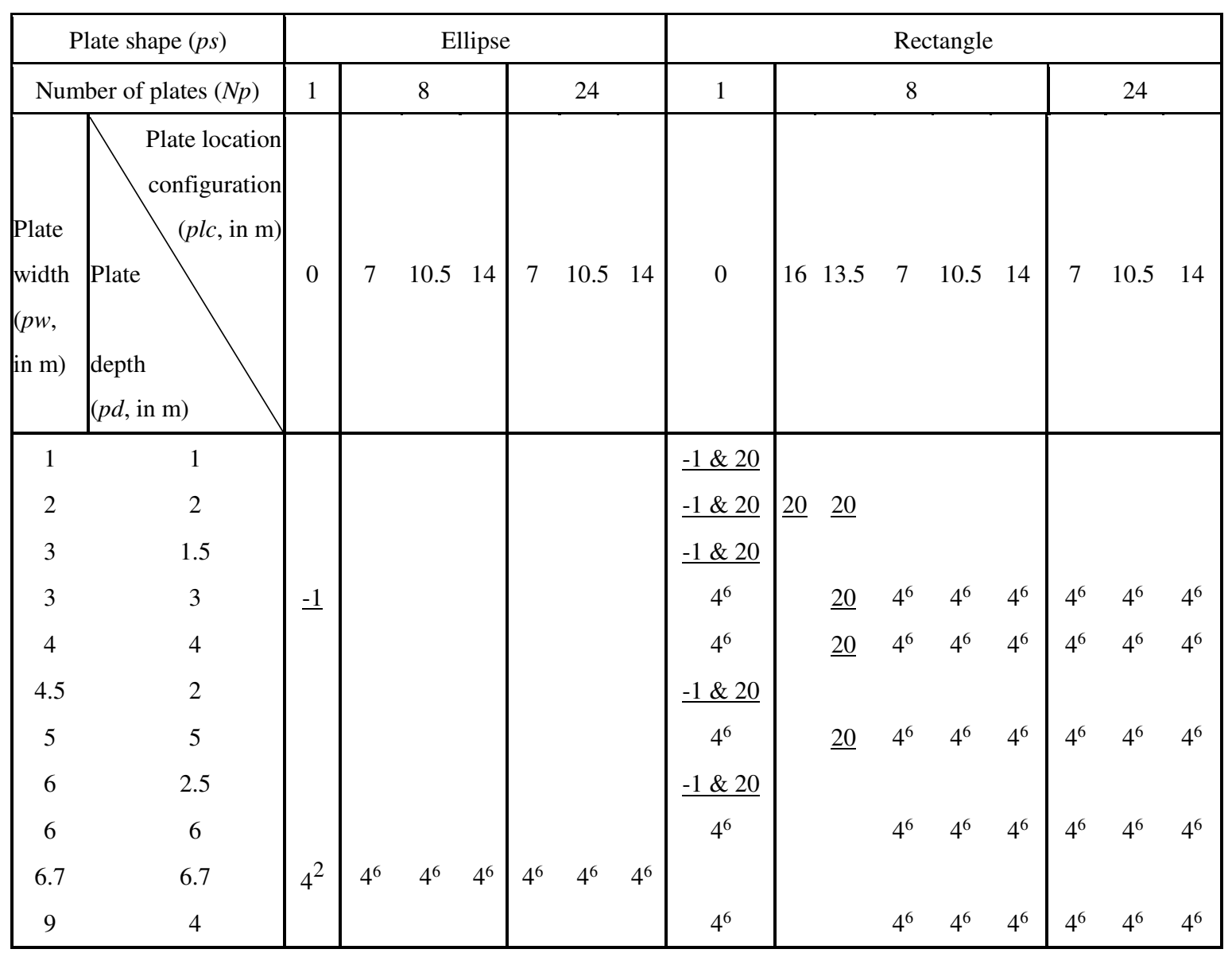

361 Table 3 provides a review of combinations of the parameters $(d, s$, and $q)$ considered in this

362 research. The sites considered in this study were two sites of class D and E (with reference

363 to the first column of Table 3) near the site of DanWEC in Denmark, the site of Ebeye in the

\footnotetext{
2 When a configuration assesses all $\mathrm{h}$, the cell number is " 4 "; otherwise, the underlined numbers show the exact h value(s).
} 
364 Marshall Islands (class A), Alidhoo in the Maldives (class B), Antofagasta in Chile (class A),

365 and Malta (class C).

366 Table 3. External parameters relationship of the sites

\begin{tabular}{lllll}
\hline $\begin{array}{c}\text { Class of } \\
\begin{array}{c}\text { combination of } \\
\text { site parameters }\end{array}\end{array}$ & $\begin{array}{c}\text { Buoy/Hindcast water } \\
\text { depth }(\mathrm{s}, \text { in } \mathrm{m})\end{array}$ & $\begin{array}{c}\text { Site water depth } \\
(\mathrm{d}, \text { in } \mathrm{m})\end{array}$ & $\begin{array}{c}\text { Wamit water depth } \\
(\mathrm{h}, \text { in } \mathrm{m})\end{array}$ & $\begin{array}{c}\text { Distance from the } \\
\text { site to shore }(\mathrm{q}, \text { in } \\
\mathrm{m})\end{array}$ \\
\hline $\mathrm{A}$ & If $\mathrm{s}>=200 \mathrm{~m}$ & 100 & -1 & 1700 \\
$\mathrm{~B}$ & Else if $\mathrm{s}>=75 \mathrm{~m}$ & 80 & -1 & 1700 \\
$\mathrm{C}$ & Else if $\mathrm{s}>=40 \mathrm{~m}$ & 50 & 50 & 4250 \\
$\mathrm{D}$ & Else if $\mathrm{s}>=25 \mathrm{~m}$ & 30 & 30 & 4250 \\
$\mathrm{E}$ & Else $\mathrm{s}<25$ & 20 & 20 & 4250 \\
\hline
\end{tabular}

368 In Table 3, only $d$ provides a unique value per line. Therefore, $d$ is solely used in the following

369 to display the impact of the site parameters.

\subsubsection{Step 3: Wavepiston WEC cost parameterisation}

371 The total Wavepiston WEC cost, $\mathrm{WEC}_{\text {Total cost, }}$ is calculated as follows:

$$
\begin{gathered}
\mathrm{WEC}_{\text {Total cost }}=\mathrm{WEC}_{\text {Base cost }}=\left(N p\left[\text { Collector }_{\text {Total cost }}+\mathrm{COA}_{\text {Total cost }}\right]+\text { String }_{\text {Total cost }}+\right.\text { Moorings } \\
\left.\mathrm{WEC}_{\text {Total cost factor }}\right)\left(1+0.01 \mathrm{WEC}_{\text {Margin }}\right),
\end{gathered}
$$

372 With $N p$ the number of plates, Collector ${ }_{\text {Total }}$ cost the total cost of a single collector and $\mathrm{COA}_{\text {Total }}$

373 cost the cost of onshore assembly. Wavepiston company estimated that the WEC dimensions

374 and site characteristics would not impact $\mathrm{COA}_{\text {Total cost }}$ and that no margin could be obtained

375 from such a task, thus, COA $\mathrm{Aotal}_{\text {cost }}$ equals its base cost $\mathrm{COA}_{\mathrm{Base}}$ cost. String Total cost and

376 Moorings Total cost are the total costs of the string and mooring, respectively. Additionally, the

377 factors estimated for the WEC sub-elements are representative enough to the several

378 phenomena affecting the costs, and so no factors were added to the overall WEC cost. As

379 Wavepiston estimated the margin over the entire WEF, the value of the margin is not 
380

distributed among the WEF and WEC elements or their sub-elements. Thus, WEC $\mathrm{Margin}_{\text {}}$ equals zero and to simplify the equations, the margins factors are not shown in the other equations since they are ineffective.

In the following, the equation for the cost of the three main elements of the WEC, namely, the collector, string, and moorings are investigated. The sub-element costs of the collector, string, and moorings, and the factors' weights were originally estimated from a detailed analysis of the subcontractor prices for the Wavepiston prototype, including the first $1 \mathrm{x} 1 \mathrm{~m}$ plate offshore test at DanWEC and the 8-plate prototype tested at Nissum Bredning [68]. During the testings of Wavepiston at scale 1:4 and 1:2, with different plate shapes at Hanstholm [52] these estimations were adjusted. Finally, these tests also provided the values of all the base costs from the smallest marketable design of Wavepiston of one string, with one rectangle plate of size $1 \times 1 \mathrm{~m}$.

\subsubsection{Collector}

The equation of the total collector cost is:

$$
\text { Collector }{ }_{\text {Total cost }}=\text { Collector }_{\text {Base cost }}+\text { Collector }_{\text {Total factor }}
$$

with Collector Base cost $=\mathrm{Pl}_{\text {Total cost }}+\mathrm{Pu}_{\text {Total cost }}+\mathrm{Be}_{\text {Total cost }}+\mathrm{Wa}_{\text {Total cost }}+\mathrm{PV}_{\text {Total cost }}+\mathrm{COP}_{\text {Total cost }}+\mathrm{CAM}_{\text {Total }}$

394 Following step 1 of the CapEx method, the total costs of the collector's sub-elements relate to plate and pump $\left(\mathrm{Pl}_{\text {Total cost }}\right.$ and $\left.\mathrm{Pu}_{\text {Total cost }}\right)$, beam $\left(\mathrm{Be}_{\text {Total cost }}\right)$, wagon (Watotal cost $)$, pipe and valves $\left(\mathrm{PV}_{\text {Total cost }}\right)$, collector's other pieces $\left(\mathrm{COP}_{\text {Total cost }}\right)$, and collector's assembly and manufacturing $\left(\mathrm{CAM}_{\text {Total cost }}\right)$. Most of the sub-elements of the collector only consist of their 
398 base cost to which is added the total factor composed of a single factor, following Equation

399 (2) with the margins equal to zeros, as mentioned before. These are summarised in Table 4

400 and details on their value are provided in Appendix A. CAM Total cost equals zero because the

401 assembly and manufacturing are carried out by Wavepiston. WaTotal cost and $\mathrm{PV}_{\text {Total cost }}$ are

402 equal to their base cost. Indeed, they are designed to support any size plate, and so their price

403 is fixed. WaTotal cost costs $550 €$ and $\mathrm{PV}_{\text {Total cost }} 800 €$. For each sub-element of the collector, the

404 base costs are the costs associated with a string composed of a single rectangular plate of size

$4051 \mathrm{x} 1 \mathrm{~m}$.

406 Table 4. Collector's sub-elements' base cost and factor

\begin{tabular}{|c|c|c|c|c|c|c|}
\hline $\begin{array}{c}\text { Sub- } \\
\text { element } \\
\text { name and } \\
\text { variable }\end{array}$ & $\begin{array}{l}\text { Sub- } \\
\text { element } \\
\text { variable }\end{array}$ & $\begin{array}{l}\text { Base } \\
\text { cost } \\
(\text { in } €)\end{array}$ & $\begin{array}{l}\text { Total } \\
\text { factor } \\
\text { name }\end{array}$ & $\begin{array}{l}\text { Factor } \\
\text { weight }\end{array}$ & $\begin{array}{c}\text { Factor } \\
\text { parameter }\end{array}$ & Comments \\
\hline Plate & $\mathrm{Pl}_{\text {Total cost }}$ & 400 & $\begin{array}{l}\text { Plate } \\
\text { total } \\
\text { factor }\end{array}$ & $60 € / \mathrm{m}^{2}$ & $p a$ & $\begin{array}{l}\text { This factor translates the } \\
\text { quantity of material to add to } \\
\text { the plate }\end{array}$ \\
\hline Pump & $\mathrm{Pu}_{\text {Total cost }}$ & 100 & $\begin{array}{l}\text { Pump } \\
\text { total } \\
\text { factor }\end{array}$ & $60 € / \mathrm{m}$ & $p w$ & $\begin{array}{l}\text { This factor is associated with } \\
\text { the scaling of the pipe to } \\
\text { engorge more or less flow }\end{array}$ \\
\hline $\begin{array}{l}\text { Other } \\
\text { pieces }\end{array}$ & $\begin{array}{c}\mathrm{COP}_{\text {Total }} \\
\text { cost }\end{array}$ & 100 & $\begin{array}{l}\text { Other } \\
\text { pieces } \\
\text { total } \\
\text { factor }\end{array}$ & $20 € / \mathrm{m}$ & $p w$ & $\begin{array}{l}\text { This factor expresses increase } \\
\text { of the other pieces for more } \\
\text { energy extraction in relation to } \\
\text { the plate width }\end{array}$ \\
\hline Beam & $\mathrm{Be}_{\text {Total cost }}$ & 400 & $\begin{array}{l}\text { Beam } \\
\text { total } \\
\text { factor }\end{array}$ & $30 € / \mathrm{m}$ & $p w$ & $\begin{array}{l}\text { This factor is associated to the } \\
\text { material required per extra } \\
\text { meter of plate }\end{array}$ \\
\hline
\end{tabular}

408 Many of these factors are based on the plate width because as a terminator-type of device,

409 the Wavepiston power absorption most influencing parameter is the length of the device

410 facing the wave crest, which is the plate width. The pipe must be capable of gorging the flow

411 actioned by the plate movement. Hence, the pump factor depends on the plate width. 


\subsubsection{String}

413 The equation for the string total cost is:

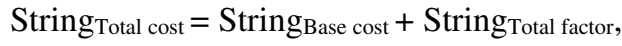

$$
\begin{aligned}
& \text { with } \mathrm{String}_{\text {Base cost }}=\mathrm{SW}_{\text {Total cost }}+\mathrm{SP}_{\text {Total cost }}+\mathrm{SC}_{\text {Total cost }}+\mathrm{MC}_{\text {Total cost }}+\mathrm{Bu}_{\text {Total cost }}+\mathrm{SOP}_{\text {Total cost }}+ \\
& \mathrm{SAM}_{\text {Total cost }}
\end{aligned}
$$

414 Following step 1 of the CapEx method, the string base cost is the sum of the string's sub-

415 elements total costs: string's wire $\left(\mathrm{SW}_{\text {Total cost }}\right)$, string's pipe $\left(\mathrm{SP}_{\text {Total cost }}\right)$, shackles and 416 connectors $\left(\mathrm{SC}_{\text {Total cost }}\right)$, monitoring and control $\left(\mathrm{MC}_{\text {Total cost }}\right)$, buoy $\left(\mathrm{Bu}_{\text {Total cost }}\right)$, string's other

417 pieces (SOP Total cost), string's assembly and manufacturing that also account for the moorings'

418 (SAM $\left._{\text {Total cost }}\right) . \mathrm{SC}_{\text {Total cost }}, \mathrm{MC}_{\text {Total cost }}, \mathrm{Bu}_{\text {Total cost }}$, and $\mathrm{SOP}_{\text {Total cost, }}$, were estimated to remain 419 the same irrespective of the string size or number of plates and so they equal their base cost.

420 The cost of $\mathrm{SC}_{\text {Total cost }}$ is $600 €, \mathrm{MC}_{\text {Total cost }} 3000 €$, and $\mathrm{SOP}$ Total cost $4500 €$. Bu $\mathrm{Butal}_{\text {cost }}$ is $8000 €$, 421 the cost of the two buoys (one at each end of the string).

$$
\mathrm{SW}_{\text {Total cost }}=\mathrm{SW}_{\text {Base cost per meter }} N p p l c+\mathrm{SW}_{\text {Total factor } 1}+\mathrm{SW}_{\text {Total factor 2, }}
$$

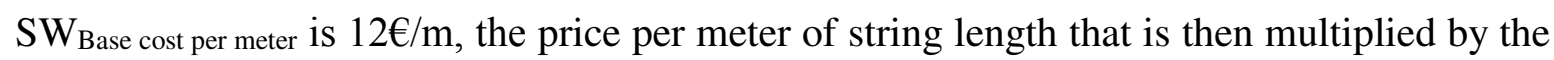
total length of the string obtained as the product of the number of plates and the distance between them. Similarly, to the string wire, the string pipe base cost depends on the string length and its base cost per meter of string length ( $\mathrm{SP}_{\mathrm{Base}}$ cost per meter) is $9 € / \mathrm{m}$. The factors of both sub-elements are summarised in 


$$
\mathrm{SP}_{\text {Total cost }}=\mathrm{SP}_{\text {Base cost per meter }} N p p l c+\mathrm{SP}_{\text {Base cost }}+\mathrm{SP}_{\text {Total factor }}
$$

429 Table 5. String's sub-elements' base cost and factor

\begin{tabular}{|c|c|c|c|c|c|}
\hline $\begin{array}{l}\text { Total } \\
\text { factor } \\
\text { name }\end{array}$ & $\begin{array}{l}\text { Factor } \\
\text { name }\end{array}$ & $\begin{array}{c}\text { Factor } \\
\text { variable }\end{array}$ & $\begin{array}{l}\text { Factor } \\
\text { weight }\end{array}$ & $\begin{array}{c}\text { Factor } \\
\text { paramete } \\
\mathrm{r} \\
\end{array}$ & Comments \\
\hline $\begin{array}{l}\text { String } \\
\text { wire total } \\
\text { factor }\end{array}$ & $\begin{array}{l}\text { String } \\
\text { wire } \\
\text { factor } 1\end{array}$ & $\begin{array}{c}\mathrm{SW}_{\text {Total factor }} \\
1\end{array}$ & $400 €$ & $N p$ & $\begin{array}{l}\text { This factor expresses the cost } \\
\text { impact of the sockets and start-up } \\
\text { of the wire production }\end{array}$ \\
\hline Pump & $\begin{array}{l}\text { String } \\
\text { wire } \\
\text { factor } 2\end{array}$ & $\begin{array}{c}\mathrm{SW}_{\text {Total factor }} \\
2\end{array}$ & $300 €$ & $N p$ & $\begin{array}{c}\text { This factor translates the cost } \\
\text { impact of fishplates and specific } \\
\text { non-standard shackles }\end{array}$ \\
\hline $\begin{array}{l}\text { String } \\
\text { pipe total } \\
\text { factor }\end{array}$ & $\begin{array}{l}\text { String } \\
\text { pipe } \\
\text { factor }\end{array}$ & $\mathrm{SP}_{\text {Total factor }}$ & $20 €$ & $N p$ & $\begin{array}{l}\text { An additional base cost of } 20 € \text { is } \\
\text { added to the base cost per meter for } \\
\text { the end caps }\end{array}$ \\
\hline
\end{tabular}

\subsubsection{Moorings}

433 The total moorings cost is:

$$
\begin{aligned}
& \text { Moorings }_{\text {Total cost }}=\text { Moorings }_{\text {Base cost }}+\text { Moorings }_{\text {Total factor }} \text {, } \\
& \text { with MooringS } \mathrm{S}_{\text {Base cost }}=\mathrm{MW}_{\text {Total cost }}+\mathrm{Ch}_{\text {Total cost }}+\mathrm{Sh}_{\text {Total cost }}+\mathrm{An}_{\text {Total cost }} \text {, }
\end{aligned}
$$

434 Following step 1 of the CapEx method, the total costs of the moorings' sub-elements relate

435 to moorings' wires $\left(\mathrm{MW}_{\text {Total cost }}\right)$, chains $\left(\mathrm{Ch}_{\text {Total cost }}\right)$, shackles $\left(\mathrm{Sh}_{\text {Total cost }}\right)$, and anchors

436 (An $\left.{ }_{\text {Total cost }}\right)$. The moorings already designed to handle extreme conditions are not associated

437 with additional factors, however, they depend on site characteristics:

$$
\mathrm{MW}_{\text {Total cost }}=\mathrm{MW}_{\text {Base cost per meter }} 4 d+\mathrm{MW}_{\text {Base cost }},
$$


440 this was extended to four so that it becomes three times the site water depth in addition to the 441 original site water depth. It assumed that $40 \mathrm{~m}$ of chain is required per moorings and therefore $442 \mathrm{Ch}_{\text {Total cost }}$ is:

$$
\mathrm{Ch}_{\text {Total cost }}=40 \mathrm{Ch}_{\text {Base cost per meter, }}
$$

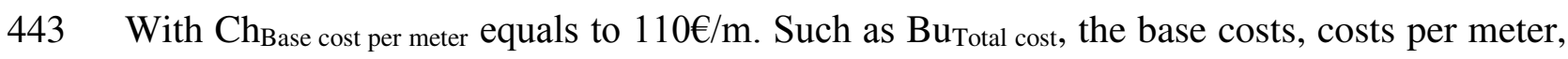

444 are for two mooring's wires for $\mathrm{MW}_{\text {Total cost }}$ and two chain for $\mathrm{Ch}_{\text {Total cost. }}$ Similarly, $\mathrm{An}_{\text {Total cost }}$ 445 is the cost of the two anchors of $40 \mathrm{~K} €$, and $\mathrm{Sh}_{\text {Total cost }}$ gathers the total cost of the eight 446 shackles (four shackles per moorings) that is of $7.5 \mathrm{~K} €$.

\subsection{SimiLITUDE METHOD APPLIED TO WAVEPISTON WEC}

Two parameters were selected to be the "Scale" from Equation (4), to apply the Similitude method from de Andres et al. [35] to Wavepiston, following Froude law similitude representative dimension: Wavepiston plate width and total length.

Table 6 provides the dimension of the source-dependency of each element and sub-element of Wavepiston WEC following the example provided by de Andres et al. [35] using CorPower WEC. Despite being similar, some elements from CorPower do not have the same functionality as for Wavepiston. For instance, CorPower WEC's buoy functionality dimension is the area because it is the contact of the buoy surface area with the waves that enables harvesting the wave power, whereas Wavepiston WEC's buoys (and attached moorings) functionality is to maintain the tension in the string and so the buoy functionality dimension is the force. 
460 Table 6. Functionality-related dimension of Wavepiston WEC elements and sub-elements 461 following de Andres et al. [35]

462

\begin{tabular}{|c|c|c|c|c|c|c|c|}
\hline $\begin{array}{l}\text { Wavepiston } \\
\text { WEC } \\
\text { elements }\end{array}$ & $\begin{array}{l}\text { Function } \\
\text { dimension }\end{array}$ & $\begin{array}{l}\text { Collector } \\
\text { sub- } \\
\text { elements }\end{array}$ & $\begin{array}{l}\text { Function } \\
\text { dimension }\end{array}$ & $\begin{array}{l}\text { String sub- } \\
\text { element }\end{array}$ & $\begin{array}{l}\text { Function } \\
\text { dimension }\end{array}$ & $\begin{array}{l}\text { Mooring } \\
\text { sub- } \\
\text { elements }\end{array}$ & $\begin{array}{c}\text { Function } \\
\text { dimension }\end{array}$ \\
\hline Collector & Force & Plate & Area & $\begin{array}{l}\text { Pipe and } \\
\text { valves }\end{array}$ & $\begin{array}{l}\text { Volume } \\
\text { flow rate }\end{array}$ & $\begin{array}{l}\text { Wire } \\
\text { rope }\end{array}$ & Force \\
\hline String & Force & Pump & Pressure & $\begin{array}{l}\text { Shackles } \\
\text { and } \\
\text { connectors }\end{array}$ & Force & Chain & Force \\
\hline $\begin{array}{l}\text { Other } \\
\text { pieces }\end{array}$ & Force & Beam & Force & Wire rope & Force & Shackles & Force \\
\hline \multirow[t]{5}{*}{ Tasks } & \multirow[t]{5}{*}{$\begin{array}{l}\text { Mass/ } \\
\text { Volume }\end{array}$} & Wagon & Acceleration & Buoys & Force & \multirow[t]{5}{*}{ Anchor } & \multirow[t]{5}{*}{ Force } \\
\hline & & $\begin{array}{l}\text { Pipe and } \\
\text { valves }\end{array}$ & $\begin{array}{c}\text { Volume flow } \\
\text { rate }\end{array}$ & Other pieces & Force & & \\
\hline & & $\begin{array}{l}\text { Other } \\
\text { pieces }\end{array}$ & Area & $\begin{array}{l}\text { Monitoring } \\
\text { and control }\end{array}$ & Power & & \\
\hline & & Tasks & $\begin{array}{c}\text { Mass/ } \\
\text { Volume }\end{array}$ & Moorings & Force & & \\
\hline & & & & Tasks & $\begin{array}{c}\text { Mass/ } \\
\text { Volume }\end{array}$ & & \\
\hline
\end{tabular}

463 Four approaches to calculate the weighted scale coefficient in Equation (4) are investigated

464 here. The first consists of averaging all scale parameters to estimate the weighted scale

465 parameter. In addition, the average is calculated for all elements of Table 6 (index 1 in Table

466 7), as well as only the sub-elements (index 2). Index 3 averages is the total average of the 467 average of the elements' average of its sub-element functionality dimensions include the 468 element's scale parameter. The last approach (index 4) relies on the Wavepiston WEC's 469 elements designed scale parameters.

470 Table 7. Weighted scale factors

\begin{tabular}{ccc}
\hline $\begin{array}{c}\text { Weighted scale coefficient } \\
\text { calculation approach index }\end{array}$ & $\begin{array}{c}\text { Weighted scale coefficient calculation } \\
\text { approach }\end{array}$ & $\begin{array}{c}\text { Weighted scale coefficient } \\
\text { value }\end{array}$ \\
\hline 1 & Average over elements and sub- \\
elements & 2.674 \\
\hline
\end{tabular}




\begin{tabular}{ccc}
\hline 2 & Average over all the sub-elements & 2.625 \\
3 & Average of the sub-elements' averages & 2.866 \\
4 & Average over the elements & 3 \\
\hline
\end{tabular}

472

\section{RESUlTS AND DISCUSSION}

474 This section is divided into two. The first sub-section first presents and discusses the sub-

475 element cost and factor values obtained for Wavepiston dataset, and then Wavepiston WEC 476 cost using the CapEx method is investigated. The second sub-section presents Wavepiston 477 WEC cost obtained using the Similitude method and the discussion aims to discuss these 478 results in relation to the Froude law similitude, as well as comparing them with the results 479 from the CapEx method.

\subsection{WAVEPISTON WEC COST AND SUB-COSTS USING THE CAPEX METHOD}

481 The effect of the factors on the sub-element costs are first investigated in this section. Then, 482 the costs of Wavepiston WEC for the whole database are provided.

\subsubsection{Wavepiston WEC elements' costs}

484 To summarise Section 3.1.3., the collector's factors mostly depend on the plate size (its area 485 and width), the string's on the number of plates and distance between the plates, and the 486 moorings' on the distance to shore. Table 8 provides the total collector cost in function of the 487 parameters above, Table 9 for the string, and Table 10 for the moorings. To help with the 488 reading of the following tables, a heat map was added with red representing the highest costs 489 and blue the lowest, which applies separately for each column of Table 8 and Table 9, and 490 over all the columns of Table 10. 
491 Table 8. Collector cost - Equation (6) - and their total factors for the combination of the 492 relevant parameters

493

\begin{tabular}{ccccccccc}
\hline $\begin{array}{c}\text { Plate } \\
\text { shape } \\
(\mathrm{sp}, \text { in -- })\end{array}$ & $\begin{array}{c}\text { Plate } \\
\text { width } \\
(\mathrm{pw} \text {, in } \\
\mathrm{m})\end{array}$ & $\begin{array}{c}\text { Plate } \\
\text { depth } \\
(\mathrm{pd}, \text { in } \mathrm{m})\end{array}$ & $\begin{array}{c}\text { Plate area } \\
\left(\mathrm{pa}, \text { in } \mathrm{m}^{2}\right)\end{array}$ & $\begin{array}{c}\text { Collector } \\
\text { total cost } \\
\text { (in } €)\end{array}$ & $\begin{array}{c}\text { Plate } \\
\text { total } \\
\text { factor } \\
\text { (in } €)\end{array}$ & $\begin{array}{c}\text { Pump } \\
\text { total } \\
\text { factor } \\
\text { in } €)\end{array}$ & $\begin{array}{c}\text { Beam } \\
\text { total } \\
\text { factor } \\
\text { (in } €\end{array}$ & $\begin{array}{c}\text { Other } \\
\text { pieces total } \\
\text { factor } \\
\text { (in } €)\end{array}$ \\
\hline rectangle & 1 & 1 & 1 & 2,370 & 60 & 60 & 30 & 20 \\
rectangle & 2 & 2 & 4 & 2,660 & 240 & 120 & 60 & 40 \\
rectangle & 3 & 1.5 & 4.5 & 2,800 & 270 & 180 & 90 & 60 \\
ellipse & 3 & 3 & 7.07 & 2,954 & 424 & 180 & 90 & 60 \\
rectangle & 3 & 3 & 9 & 3,070 & 540 & 180 & 90 & 60 \\
rectangle & 4.5 & 2 & 9 & 3,235 & 540 & 270 & 135 & 90 \\
rectangle & 4 & 4 & 16 & 3,600 & 960 & 240 & 120 & 80 \\
rectangle & 6 & 2.5 & 15 & 3,760 & 900 & 360 & 180 & 120 \\
rectangle & 5 & 5 & 25 & 4,250 & 1,500 & 300 & 150 & 100 \\
rectangle & 6 & 6 & 36 & 5,020 & 2,160 & 360 & 180 & 120 \\
ellipse & 6.7 & 6.7 & 35.26 & 5,052 & 2,115 & 402 & 201 & 134 \\
rectangle & 9 & 4 & 36 & 5,350 & 2,160 & 540 & 270 & 180 \\
\hline
\end{tabular}

494 Table 8 shows that Wavepiston PTO, which is its collector, is below the $6 \mathrm{~K} €$ estimated by

495 Clark et al. [28]. The Wavepiston PTO cost is very close to the Oscillating Water Column

496 (OWC) and fixed Oscillating Wave Surge Converter (OWSC) from de Andres et al. [69]

497 obtained from the reversed LCoE method giving PTO values around 1.1K€. In contrast, these

498 values are above the PTO of floating OWSC, and for the overtopping and heaving WEC

499 around 5.5K€ (conversion from British pound sterling, £1=1.1005€) [69].

500 Most of the factors in Table 8 are consistent with the dependency of the collector cost on the

501 parameters, aside from the rectangle plates from $9 \mathrm{~m}^{2}$ with $p w=4.5 \mathrm{~m}$ to $25 \mathrm{~m}^{2}$. All the factors

502 of these lines have colors that no longer match those of the collector cost. Especially, the

503 factors of the pump, beam, and other pieces are reversed for $9 \mathrm{~m}^{2}$ and $16 \mathrm{~m}^{2}$, in the sense that

504 where the collector cost is higher for $16 \mathrm{~m}^{2}$, and lower for $9 \mathrm{~m}^{2}$, these factors have higher

505 value for $9 \mathrm{~m}^{2}$ instead. This is also the case for $15 \mathrm{~m}^{2}$ and $25 \mathrm{~m}^{2}$, and it is due to their 
506 dependency on $p w$. Moreover, the plate total factors are also reversed for the $16 \mathrm{~m}^{2}$ and for

$50715 \mathrm{~m}^{2}$. Therefore, despite being linear functions, the factors can diverge from each other and

508 result in an even different behaviour of the total cost.

509 Table 9. String cost - Equation (8) - and their total factors obtained for the relevant 510 parameters

\begin{tabular}{cccccc}
\hline $\begin{array}{c}\text { Number of plates } \\
(\mathrm{Np}, \text { in -- }\end{array}$ & $\begin{array}{c}\text { Distance between } \\
\text { plates } \\
(\mathrm{plc}, \text { in } \mathrm{m})\end{array}$ & $\begin{array}{c}\text { String total cost } \\
\text { (in } €)\end{array}$ & $\begin{array}{c}\text { String pipe } \\
\text { total factor } \\
\text { (in } € \text { ) }\end{array}$ & $\begin{array}{c}\text { String wire } \\
\text { factor 1 } \\
\text { (in } €)\end{array}$ & $\begin{array}{c}\text { String wire } \\
\text { factor } 2 \\
\text { (in } €)\end{array}$ \\
\hline 1 & 0 & 18,717 & 25 & 400 & 300 \\
8 & 7 & 25,472 & 200 & 3,200 & 2,400 \\
8 & 10.5 & 26,648 & 200 & 3,200 & 2,400 \\
8 & 13.5 & 27,656 & 200 & 3,200 & 2,400 \\
8 & 14 & 27,824 & 200 & 3,200 & 2,400 \\
8 & 16 & 28,496 & 200 & 3,200 & 2,400 \\
24 & 7 & 41,776 & 600 & 9,600 & 7,200 \\
24 & 10.5 & 45,304 & 600 & 9,600 & 7,200 \\
24 & 14 & 48,832 & 600 & 9,600 & 7,200 \\
\hline
\end{tabular}

512 Table 9 shows that generally the trend of the string total cost can be divided into three

513 categories of costs for each number of plates. Then, as 8-plate and 24-plate categories are

514 characterised by diverse distances between plates, the string total cost is nuanced within these

515 categories, increasing with this distance. Disregarding the margin effect, the sum of the total

516 factors represent approximatively $4 \%$ for 1 -plate, $21 \%$ for 8 -plate, and 39\% for 24-plate, of

517 the string cost, which is mostly affected by the wire factors (the string pipe contribution

518 increasing linearly by only $0.6 \%$ from $0.1 \%$ for $N p=1$ ). Consequently, the more plates there

519 are on the string, the more the factors affect the string cost. 
520 Table 10. Mooring cost - Equation (12) - in function of the relevant parameters

\begin{tabular}{cccccc}
\hline $\begin{array}{c}\text { Wamit water } \\
\text { depth } \\
(\mathrm{h}, \text { in } \mathrm{m})\end{array}$ & $\mathrm{d}=100$ & $\mathrm{~d}=80$ & $\mathrm{~d}=50$ & $\mathrm{~d}=30$ & $\mathrm{~d}=20$ \\
\hline $\mathrm{h}>=100$ & 55,800 & 55,240 & -- & -- & -- \\
50 & -- & -- & 54,400 & -- & -- \\
30 & -- & -- & -- & 53,840 & -- \\
20 & -- & -- & -- & -- & 53,560 \\
\hline
\end{tabular}

522 All in all, Table 8-Table 10 confirm the expectations that the element costs increase greatly

523 with the number of plates (thereby collectors), reasonably with the plate size (especially its

524 width), marginally with the distance between plates, and slightly with the water depth. In this

525 situation, it is worth noting that the moorings have the lowest rate of change under the effect

526 of the present parameterisation (Table 10), which is probably due to the absence of factors.

527 Indeed, despite the obvious cost increase with parameter size (since all weights are positives),

528 independently or combined, the factors have various, and possibly strong, impacts on the

529 costs. Therefore, the factorisation should be conducted carefully with consideration of upper

530 and lower effects on the costs for each type of WEC and its elements.

\section{4.1.2 Wavepiston WEC cost}

532 Figure 4 provides the spread of the Wavepiston WEC costs over the site water depth 533 parameters (top picture) for the different configurations of Wavepiston that are shown in the 534 bottom section of the figure. 

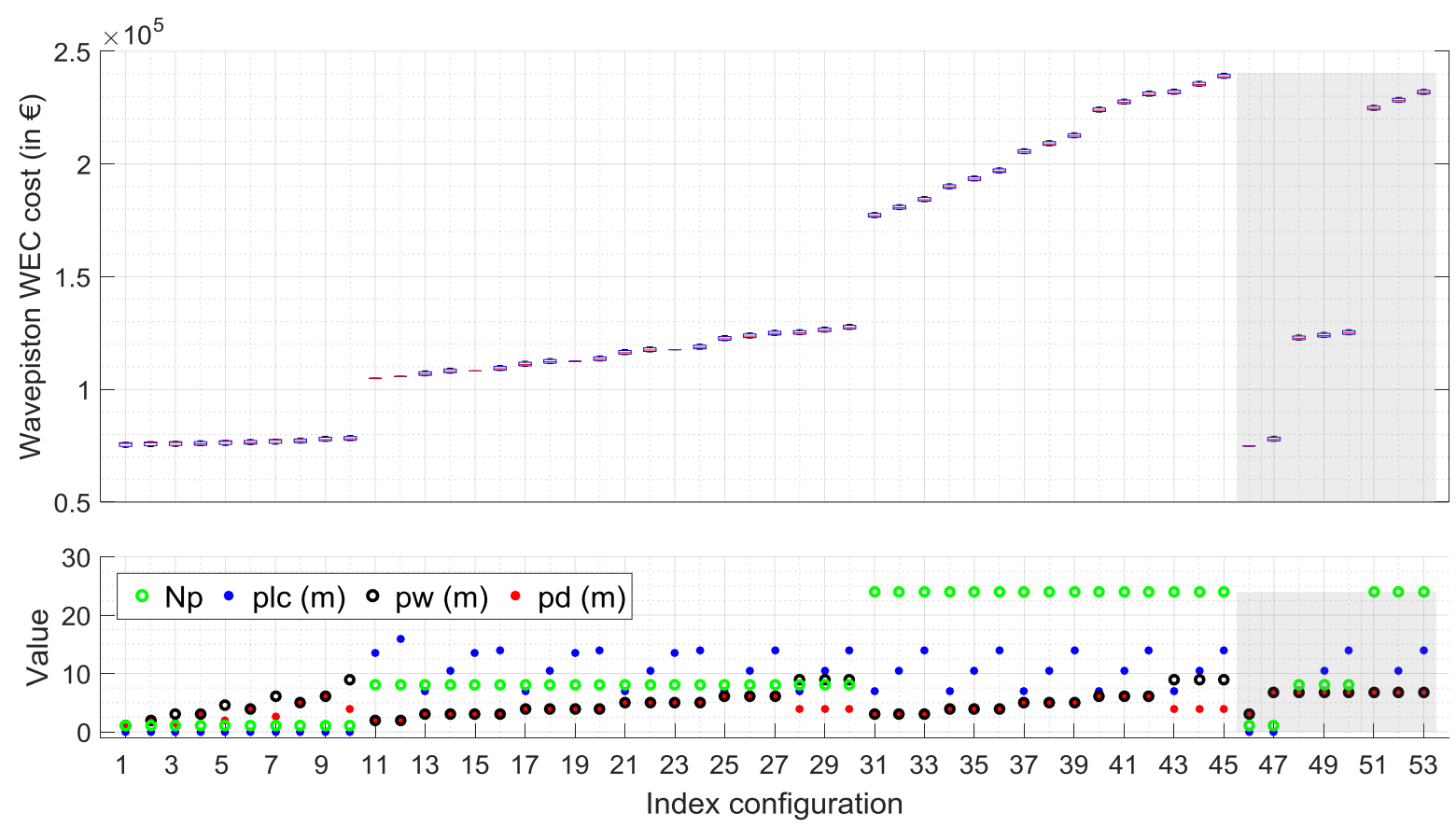

536 Figure 4. Boxplot that shows the spread of the WEC cost (in $€$ ) over the site water depth (see Table 3) clustered per similar configuration of Wavepiston of the other Wavepiston WEC configuration parameters (see Table 2 and Table 3 for parameter definition and values), the grey sections for the elliptical plates

In Figure 4, all configurations are based on the Wavepiston WEC configuration parameters, excluding the wamit water depth $(h)$ such that the spread of the boxplot is only affected by the site parameters and $h$. This spread is very narrow in comparison to the rate of overall change of the clusters from the effect of the number of plates and plate distance ( $\mathrm{Np}$ and $\mathrm{plc}$, respectively), and the plate width and depth ( $p w$ and $p d$, respectively). This is mostly due to small mooring costs variations visible in Table 10. Consequently, $h$ and site parameters have little impact on the Wavepiston WEC cost. increases the influence of all other parameters. The second parameter is the plate area and, more specifically, the plate width. For instance, the 9-4 plate is more expensive than the 6-6 and 6.7-6.7 plates. This aligns with the collector cost from Table 8. Additionally, elliptical 
551 plates (in fact, circular plates since $p w=p d$ ) cost less than the rectangular. This price

552 difference decreases with a decrease in the $p w$ and $p d$ values. The weakest parameters to

553 influence the WEC price are $h$ and $d$. The fewer collectors there are on the string, the less plc

554 affects the WEC cost, but can eventually make it a weak parameter as well.

555 Eventually, Wavepiston WEC cost for the largest device is similar to the estimation 556 calculated manually from Wavepiston. It is worth noting that the company expects to reduce 557 the mooring expenses by half with time and experience. Wavepiston has asked this estimation 558 to remain confidential.

4.2 WAVEPISTON WEC COSTS USING THE SIMILITUDE METHOD AND COMPARISON WITH WAVEPISTON WEC COSTS FROM THE CAPEX METHOD

561 The cost of a rectangular 1x1 m 1-plate Wavepiston WEC is 67,564€. Table 11 and Table 12

562 provide Wavepiston WEC cost obtained from the Similitude method using the plate width 563 and the string length, respectively. In both tables, a heat map, from red to white to blue, was 564 provided so that the darkest red cell is the highest value of the entire table, and the darkest 565 blue reflects the lowest. 


\begin{tabular}{ccccc}
\hline \multirow{2}{*}{$\begin{array}{c}\text { Plate width } \\
\text { (pw, in m) }\end{array}$} & $\begin{array}{c}\text { Sub-elements } \\
\text { only }\end{array}$ & $\begin{array}{c}\text { Weighted scale coefficient } \\
\text { Elements and sub- } \\
\text { elements }\end{array}$ & $\begin{array}{c}\text { Elements averaged } \\
2.866\end{array}$ & $\begin{array}{c}\text { Elements function } \\
\end{array}$ \\
2.625 & 416,792 & 431,191 & 492,569 & 5 \\
\hline 2 & $1,208,255$ & $1,275,080$ & $1,574,508$ & $1,824,228$ \\
3 & $2,571,123$ & $2,751,844$ & $3,591,032$ & $4,324,096$ \\
4 & $3,502,662$ & $3,770,558$ & $5,032,948$ & $6,156,770$ \\
4.5 & $4,618,613$ & $4,997,596$ & $6,807,120$ & $8,445,500$ \\
5 & $7,453,537$ & $8,137,515$ & $11,478,809$ & $14,593,824$ \\
6 & $9,957,761$ & $10,930,484$ & $15,748,737$ & $20,320,751$ \\
7 & $21,607,372$ & $24,063,557$ & $36,692,253$ & $49,254,156$ \\
9 & & & & \\
\hline
\end{tabular}

Table 11 provides for each plate width (left column) the results of the Similitude method scaling using the weighted scale coefficients for the four approaches presented in Section 3.2. Table 11 shows that the greater the scaling factor, the higher the difference between the results of larger weighted scale coefficients, which leads to more expensive WECs. The weighted factor providing the closest results to the CapEx method is the first entitled "Subelements only", which consists of averaging the scale parameters for all sub-elements excluding the element designed function dimension. It seems to be the most consistent application of the Similitude method with the approach of the last column (average over the designed function dimensions only), although the last-column approach provides the highest results. Henceforth, only these two approaches are presented and discussed below. as the parameter increases. In fact, the strict application of the Froude law implies a linear increase of all parameters with the coefficient of increase provided as the scaling factor to a power associated with the dimension of the considered quantity (see Table 1). For instance, 
583 for $p w=2 \mathrm{~m}$ (scale factor of 2 ), then $p d=1 \times 2^{1}=2 \mathrm{~m}$ and $p a=1 \times 2^{2}=4 \mathrm{~m}^{2}$. As such, each line of 584 Table 11 (and Table 12) is associated with a very precise WEC configuration and especially 585 they are associated with the number of plates $(\mathrm{Np})$ equals to 1 since the WEC base cost is for $586 N p=1$; and because $N p$ is dimensionless, it does not scale up as the scale parameter equals 587 zero (Table 1). Therefore, from Table 11, only the costs for $p w$ below $3 \mathrm{~m}$ could be 588 approximated to the CapEx method with $N p=1$.

589 Moreover, due to the strong dependency of Wavepiston on $N p$, to estimate the values of 590 scaled up Wavepiston for $N p$ different from 1, the same process used to obtain Table 11 591 should be applied to a base cost still estimated for $1 \times 1 \mathrm{~m}$-plate but for the enquired number 592 of plates. The simplest design of 8-plate and 24-plate Wavepiston WEC are obtained for 593 plates distanced (plc) by $7 \mathrm{~m}$, which must also be considered alongside the number of plates. 594 Indeed, some element base costs (see Section 3.1.3.) depend on plc. For the 8-plate design 595 the base cost is estimated to be $86,093 €$ and for 24 -plate, $128,445 €$, for which the results are 596 provided in Figure 5. Eventually, for plate width of $1 \mathrm{~m}$, the Similitude method results equal 597 the base cost resulting in a starting point always below the CapEx method minimum 598 boundaries for each category of number of plates. 


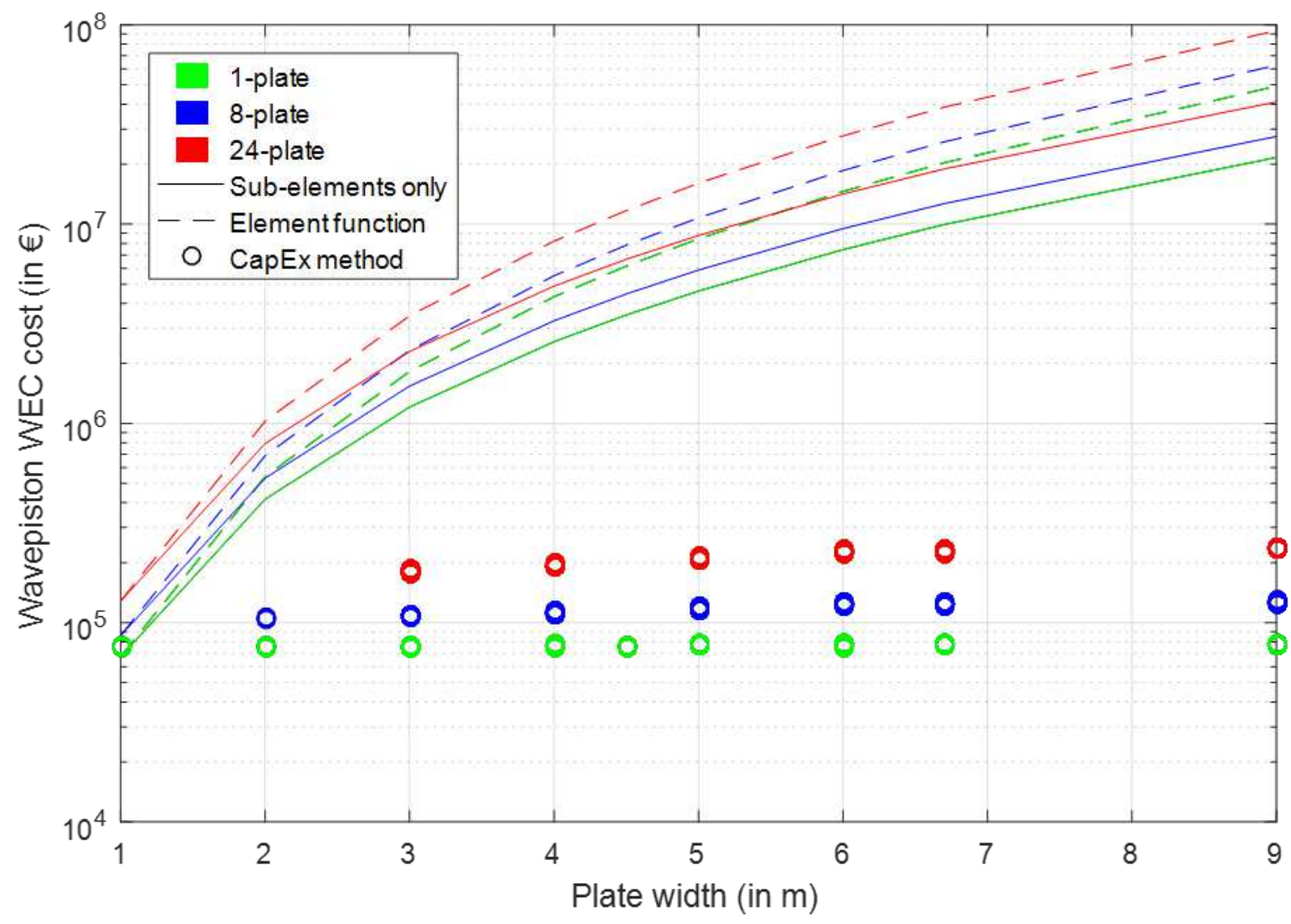

600 Figure 5. Wavepiston WEC cost (in $€$ ) using the Similitude method over the plate width for 601 the "Sub-element only" and "Element function" weighted scale coefficient results from the 602 CapEx method for the three values of number of plates from the dataset Figure 5 shows a clear discrepancy between the results of the Similitude and CapEx methods such that the results obtained with the Similitude method can be 5-529 times higher than those of the CapEx method. In fact, the difference between the two methods reduces with increasing number of plates and the "Element function" provides the most significant difference. Considering the "Sub-element only" weight scale coefficient, the results of the

608 Similitude method reach up to 146 times of those of the CapEx method, for the 24-plate configuration, and 232, for the 1-plate. This difference is reduced to 36 for 24-plate and 58

610 for 1-plate. In effect, the Similitude method based on the plate width parameter can be 611 compared to Wavepiston for size below $3 \mathrm{~m}$, and the larger number of plate is, the closer are 612 the results from the two methods. Yet, due to the limited dataset, no concrete conclusion can 
613 be provided to determine a limit of number of plates over which the Similitude method,

614 simpler to apply, could be used instead of the CapEx method, more complex, to estimate

615 Wavepiston WEC costs.

616 It is reasonable to notice that given the values of the parameters, any Wavepiston WEC cost

617 above $10 \mathrm{M} €$ is unrealistic. Therefore, the results from Table 12 shows that the string length

618 parameter tested as an alternative "Scale" parameter (Equation (4)) to apply the Similitude

619 method cannot be used for Wavepiston. A third parameter consisting of the plate width

620 multiplied by the number of plates was also considered as a combination of the two major

621 parameters for Wavepiston power absorption, however similarly to Table 12 all results were

622 above a billion euros and so were disregarded from the study. Consequently, amongst the

623 three different "Scale" parameters tested to apply the Similitude method to Wavepiston, the

624 closest results to the CapEx method are obtained from the plate width, henceforth the analysis

625 of the other parameters are not extended to the 8-plate and 24-plate Wavepiston.

626 Table 12. Wavepiston WEC cost (in €) using the Similitude method over the string length

\begin{tabular}{cccc}
\hline $\begin{array}{c}\text { Plate-location } \\
\text { configuration } \\
(\text { plc, in })\end{array}$ & $\begin{array}{c}\text { Number of Plates } \\
(\mathrm{Np}, \text { in -- })\end{array}$ & Sub-elements only 2.625 & Elements function 3 \\
\hline 7 & 8 & $14,452,744,628$ & $76,129,865,280$ \\
10.5 & 8 & $27,954,682,319$ & $161,803,707,840$ \\
13.5 & 8 & $30,754,913,691$ & $180,455,976,960$ \\
14 & 8 & $43,665,996,277$ & $269,368,688,640$ \\
16 & 8 & $89,156,716,886$ & $609,038,922,240$ \\
7 & 24 & $258,460,168,206$ & $2,055,506,362,560$ \\
10.5 & 24 & $549,993,815,757$ & $4,872,311,377,920$ \\
14 & 24 & $14,452,744,628$ & $76,129,865,280$ \\
\hline
\end{tabular}

628 In the case of Wavepiston, each parameter has a specific impact on the energy absorption,

629 sizing of the WEC, and thereby costs, which was found to diverge from the Froude law 
630 scaling concerning the costs. Consequently, the Similitude method has not been shown to be

631 appropriate to scale the costs of Wavepiston as opposed to the CapEx method that enables

632 the selection of specific parameters impact on the costs.

\section{SUMMARY AND CONCLUSION}

634 This study presents the generic "CapEx method" with application to the wave renewable

635 energy field. The CapEx method aims to provide a systematic and comprehensive approach

636 for WEC and WEF cost parameterisation to enable future calculations of large datasets of

637 WEC, WEF, and site characteristics to select optimised pairs of WEC/WEF configuration

638 and site. This method distinguishes WEC and WEF elements and sub-elements, an element

639 and sub-elements being a system, module, component, piece, or task, in the calculations.

640 Then, tasks such as manufacturing and assembling, are assigned to the different parts. For

641 each element and sub-element, a base cost, a margin, and one or more factors are estimated.

642 In its simplest form, the CapEx method appears as an ordinary cost estimation leading to an

643 overall sum of costs with margins. In the alternative approach, the factors enable the

644 encapsulation of several phenomena concerning site characteristics, and WEC and WEF

645 configurations. In its advanced form, more abstract elements can be included such as

646 economies of scale and weather and wave climate influence on the costs of the element and

647 sub-elements of the WEC and WEF, through the factors leading to the complex parameterised

648 CapEx calculation.

649 In this article, the CapEx method was applied to a Wavepiston farm to estimate the

650 Wavepiston WEC cost for different WEC configuration and site characteristics. This 
651

652

653

654

example is an intermediate use of the CapEx method to allow the research to focus more on the two first steps of the CapEx method. Indeed, one of the significant challenges of this research was to handle limited and complex databases of configurations such as the one provided by Wavepiston. This complexity is due to the selected parameters and their limited number of combinations. Consequently, one of the contributions of this study is the approach to describe, understand, and use such a database as required by the first two steps of the CapEx method.

The cost of Wavepiston WEC for the limited configurations available from the database ranges between $66 \mathrm{~K} €$ (for 1-plate 1x1m Wavepiston WEC) to $240 \mathrm{~K} €$ (for 24-9x4m plates distanced by $14 \mathrm{~m}$ ) bearing in mind that these WEC dimensions are more theoretical than practical as Wavepiston estimates the first commercial system to consist of 32 plates or energy collector. The number of plates was found to be the most influencing parameter on the WEC cost, also increasing other parameters affect as it increases. The plate dimensions and especially the plate width were the second most influent parameters. It was also found that the factors could represent more than $30 \%$ of the costs and their combination could lead to cost trends over the parameters differing from each factor trend. Finally, the study showed that Wavepiston WEC cost parameterised using the CapEx method resulted in the site's parameters having little effect on the WEC and WEC element costs, in comparison to other parameters such as Wavepiston's number of plates and plate width, more related to the WEC configuration. 
671 The results from the CapEx method in line with manual estimations from Wavepiston, were

672 also compared to the method of de Andres et al. [35]. It was found that (a) when considering

673 sub-elements of the WEC main elements, the weighted scale coefficient should be estimated

674 only over the sub-elements regardless the dimension associated with the top-element; (b) the

675 plate width is the most reliable parameter to apply the method to Wavepiston; (c) for low

676 values of the plate width, the Similitude and CapEx methods provide close costs; (d) the more

677 plates there are on the string, the closer the costs estimated by the CapEx and Similitude

678 methods are; and (e) despite that, due to its multi-parameterised configuration design,

679 Wavepiston cost is better estimated using the CapEx method than by the method of de Andres

680 et al. [35] that provides results up to 36 times those from the CapEx method.

681 For WEC scaling, the method of de Andres et al. [35] was extended to parameterise the cost

682 in the case of limited access to the WEF and WEC elements and sub-elements information

683 and costs. However, the application to multi-parameter WECs is limited and should be

684 conducted carefully. For a more complete access to information and costs, the CapEx method

685 was found to be a robust framework that enables flexible and transparent cost calculations

686 for both simple and complex cost parameterisation. This method allows obtaining the costs

687 for large databases of pairs of sites and WEC configurations automatically. Even though the

688 manual estimation may be more accurate, this method enables assessing site-WEC pairing

689 worldwide, which cannot be carried out manually due to the tremendous amount of 690 information. 


\section{DECLARATION}

692

AVAilability OF THE Data AND MATERials:

693 All data generated or analysed during this study are provided within the text. This includes

694 the complete dataset including the costs, factors, and equations used to undertake these

695 calculations.

696 COMPETING INTERESTS:

697 The authors declare they have no competing interest.

698 FUNDING:

699 This research did not receive any specific grant from funding agencies in the public,

700 commercial, or not-for-profit sectors.

701 Author CONTRIBUTIONS:

702 Ophélie Choupin has conducted the research, written, and revised the manuscript. Amir

703 Etemad-Shahidi provided the main supervision for the manuscript writing and carefully

704 revised the manuscript. Michael Henriksen the original supervision for the research and the

705 data for the research. Rodger Tomlinson provided supervision as well as comments and

706 revisions of the manuscript. All authors read and approved the final manuscript. 
708 Most of this research did not receive any specific grant from funding agencies in the public,

709 commercial, or not-for-profit sectors. However, the first author would like to acknowledge

710 the support from Griffith University through a Postgraduate Research Scholarship.

711 Wavepiston provided the dataset and first raw estimations of the element costs. The Technical

712 University of Denmark, provided the Energy Tool to assess the energy of Wavepiston pairs

713 of site and configuration. The authors would like to acknowledge the Institute of Advanced

714 Industrial Technologies (ESTIA) that enabled this research. A final thanks to Harry Bingham,

715 Robert Read, Karl Jenkins, and Fernando Pinheiro Andutta, who provided many constructive

716 comments and feedback to improve the study.

717 FIGURE COLORS:

718 Colors should be used for Figure 2, 5, and 6, as well as Table 5-9, in print. All other figures

719 and tables are in black and white and do not need colors.

\section{NOMENClATURE}

\begin{tabular}{lll}
\hline List of symbols & $\mathrm{m}$ & \\
\hline$d$ & $\mathrm{~m}$ & Site water depth \\
$h$ & $\mathrm{~m}$ & WAMIT water depth \\
$H s$ & $\mathrm{~s}$ & Wave significant height \\
$T p$ & - & Wave peak period \\
$N p$ & $\mathrm{~m}$ & Wavepiston number of plates \\
$p d$ & & Wavepiston plate depth \\
& -- and $\mathrm{m}$ & Wavepiston plate location \\
$p l c$ & & configuration (associated with the \\
& -- & distance between the plates) \\
$q s$ & $\mathrm{~m}$ & Wavepiston plate shape \\
$s$ & $\mathrm{~m}$ & Distance to shore \\
$\theta p$ & degrees & Data water depth \\
& & Wave peak direction
\end{tabular}




\begin{tabular}{lll}
\hline \multicolumn{2}{l}{ List of Abbreviation /Nomenclature } & \\
\hline AEP & MWh/year & Annual Energy Production \\
CapEx & Euros & Capital Expenditure \\
LCoE & Euros/kW & Levelised Cost of Energy \\
\hline List of abbreviations & & \\
\hline 2D & 2-Dimensional space based on Hs and Tp \\
3D & 3-Dimensional space that adds $\theta p$ to Hs and Tp \\
PM & Power Matrix \\
PTO & Power-Take-Off \\
TRL & Technology Readiness Levels \\
WEC & Wave Energy Converter \\
WEF & Wave Energy Farm & \\
\hline
\end{tabular}

\section{REFERENCES}

723

724

725

726

727

728

729

730

731

732

733

734

735

736

737

738

739

740

741

742

743

744

745

746

747

748

749

750

[1] Kenny R, Law C, Pearce JM. Towards real energy economics: Energy policy driven by life-cycle carbon emission. Energy Policy 2010;38:1969-78. https://doi.org/10.1016/j.enpol.2009.11.078.

[2] MacKay DJC. Sustainable Energy - Without the Hot Air. Cambridge: Green Books; 2009.

[3] Quero García P, Chica Ruiz JA, García Sanabria J. Blue energy and marine spatial planning in Southern Europe. Energy Policy 2020;140:111421. https://doi.org/10.1016/j.enpol.2020.111421.

[4] Ram M, Aghahosseini A, Breyer C. Job creation during the global energy transition towards $100 \%$ renewable power system by 2050 . Technological Forecasting and Social Change 2020;151:119682. https://doi.org/10.1016/j.techfore.2019.06.008.

[5] Dietzenbacher E, Kulionis V, Capurro F. Measuring the effects of energy transition: A structural decomposition analysis of the change in renewable energy use between 2000 and 2014. Applied Energy 2020;258:114040. https://doi.org/10.1016/j.apenergy.2019.114040.

[6] Robertson B, Bekker J, Buckham B. Renewable integration for remote communities: Comparative allowable cost analyses for hydro, solar and wave energy. Applied Energy 2020;264:114677. https://doi.org/10.1016/j.apenergy.2020.114677.

[7] Allan G, Gilmartin M, McGregor P, Swales K. Levelised costs of Wave and Tidal energy in the UK: Cost competitiveness and the importance of "banded" Renewables Obligation Certificates. Energy Policy 2011;39:23-39. https://doi.org/10.1016/j.enpol.2010.08.029.

[8] Chang G, Jones CA, Roberts JD, Neary VS. A comprehensive evaluation of factors affecting the levelized cost of wave energy conversion projects. Renewable Energy 2018;127:344-54. https://doi.org/10.1016/j.renene.2018.04.071.

[9] Astariz S, Iglesias G. The economics of wave energy: A review. Renewable and Sustainable Energy Reviews 2015;45:397-408. https://doi.org/10.1016/j.rser.2015.01.061. 
751

752

753

754

755

756

757

758

759

760

761

762

763

764

765

766

767

768

769

770

771

772

773

774

775

776

777

778

779

780

781

782

783

784

785

786

787

788

789

790

791

[10] Shadman M, Silva C, Faller D, Wu Z, de Freitas Assad LP, Landau L, et al. Ocean Renewable Energy Potential, Technology, and Deployments: A Case Study of Brazil. Energies 2019;12:3658. https://doi.org/10.3390/en12193658.

[11] Lehmann M, Karimpour F, Goudey CA, Jacobson PT, Alam M-R. Ocean wave energy in the United States: Current status and future perspectives. Renewable and Sustainable Energy Reviews 2017;74:1300-13. https://doi.org/10.1016/j.rser.2016.11.101.

[12] de Andrés AD, Guanche R, Weber J, Costello R. Finding gaps on power production assessment on WECs: Wave definition analysis. Renewable Energy 2015;83:171-87. https://doi.org/10.1016/j.renene.2015.04.026.

[13] Prendergast J, Li M, Sheng W. A Study on the Effects of Wave Spectra on Wave Energy Conversions. IEEE Journal of Oceanic Engineering 2018:1-13. https://doi.org/10.1109/JOE.2018.2869636.

[14] Mackay EBL, Bahaj AS, Challenor PG. Uncertainty in wave energy resource assessment. Part 1: Historic data. Renewable Energy 2010;35:1792-808. https://doi.org/10.1016/j.renene.2009.10.026.

[15] Pascal RC, Gorintin F, Payne GS, Cliquet V. The right size for a WEC: a study on the consequences of the most basic design choice. Proceedings of the 7 th International Conference on Ocean Energy, Cherbourg, France, Cherbourg, France: 2018.

[16] de Andres A, Medina-Lopez E, Crooks D, Roberts O, Jeffrey H. On the reversed LCOE calculation: Design constraints for wave energy commercialization. International Journal of Marine Energy 2017;18:88-108. https://doi.org/10.1016/j.ijome.2017.03.008.

[17] Piscopo V, Benassai G, Della Morte R, Scamardella A. Cost-Based Design and Selection of Point Absorber Devices for the Mediterranean Sea. Energies 2018;11:946. https://doi.org/10.3390/en11040946.

[18] Hiles CE, Beatty SJ, De Andres A. Wave Energy Converter Annual Energy Production Uncertainty Using Simulations. Journal of Marine Science and Engineering 2016;4:53. https://doi.org/10.3390/jmse4030053.

[19] Mérigaud A, Ringwood JV. Power production assessment for wave energy converters: Overcoming the perils of the power matrix. Proceedings of the IMechE 2018;232:5070. https://doi.org/10.1177/1475090217731671.

[20] Castro-Santos L, Silva D, Bento AR, Salvação N, Guedes Soares C. Economic Feasibility of Wave Energy Farms in Portugal. Energies 2018;11:3149. https://doi.org/10.3390/en11113149.

[21] Guanche R, de Andrés A, Losada IJ, Vidal C. A global analysis of the operation and maintenance role on the placing of wave energy farms. Energy Conversion and Management 2015;106:440-56. https://doi.org/10.1016/j.enconman.2015.09.022.

[22] Lavidas George, Agarwal Atul, Venugopal Vengatesan. Availability and Accessibility for Offshore Operations in the Mediterranean Sea. Journal of Waterway, Port, Coastal, and Ocean Engineering 2018;144:05018006. https://doi.org/10.1061/(ASCE)WW.1943-5460.0000467. 
[23] O’Connor M, Lewis T, Dalton G. Operational expenditure costs for wave energy projects and impacts on financial returns. Renewable Energy 2013;50:1119-31. https://doi.org/10.1016/j.renene.2012.08.059.

[24] De Andres A, Maillet J, Hals Todalshaug J, Möller P, Bould D, Jeffrey H. TechnoEconomic Related Metrics for a Wave Energy Converters Feasibility Assessment. Sustainability 2016;8:1109. https://doi.org/10.3390/su8111109.

[25] Guanche R, de Andrés AD, Simal PD, Vidal C, Losada IJ. Uncertainty analysis of wave energy farms financial indicators. Renewable Energy 2014;68:570-80. https://doi.org/10.1016/j.renene.2014.02.046.

[26] Chozas JF, Kofoed JP, Jensen NEH. User guide - COE Calculation Tool for Wave Energy Converters: ver. 1.6 - April 2014. 1st ed. Denmark: Department of Civil Engineering, Aalborg University; 2014.

[27] Somasundaram S, Tay AAO. Performance study and economic analysis of photovoltaic thermal system under real-life thermal loads in tropical climate. Sustainable Environment Research 2019;29:34. https://doi.org/10.1186/s42834-019-0040-5.

[28] Clark CE, Miller A, DuPont B. An analytical cost model for co-located floating windwave energy arrays. Renewable Energy 2019;132:885-97. https://doi.org/10.1016/j.renene.2018.08.043.

[29] LaBonte A, O’Connor P, Fitzpatrick C, Hallett K, Li Y. Standardized cost and performance reporting for marine and hydrokinetic technologies. Proceedings of the 1st Marine Energy Technology Symposium (METS13), Washington, DC, USA, 2013, p. $10-11$.

[30] Marine Energy - System Advisor Model (SAM) n.d. https://sam.nrel.gov/marineenergy.html (accessed December 7, 2020).

[31] Neary VS, Lawson M, Previsic M, Copping A, Hallett KC, LaBonte A, et al. Methodology for Design and Economic Analysis of Marine Energy Conversion (MEC) Technologies. Sandia National Lab.(SNL-NM), Albuquerque, NM (United States); 2014.

[32] Lavidas G, Venugopal V, Friedrich D. Wave energy extraction in Scotland through an improved nearshore wave atlas. International Journal of Marine Energy 2017;17:64-83. https://doi.org/10.1016/j.ijome.2017.01.008.

[33] Castro-Santos L, Bento AR, Guedes Soares C. The Economic Feasibility of Floating Offshore Wave Energy Farms in the North of Spain. Energies 2020;13:806. https://doi.org/10.3390/en13040806.

[34] Babarit A, Hals J, Muliawan MJ, Kurniawan A, Moan T, Krokstad J. Numerical benchmarking study of a selection of wave energy converters. Renewable Energy 2012;41:44-63. https://doi.org/10.1016/j.renene.2011.10.002.

[35] de Andres A, Maillet J, Hals Todalshaug J, Möller P, Jeffrey H. On the Optimum Sizing of a Real WEC From a Techno-Economic Perspective 2016:V006T09A013. https://doi.org/10.1115/OMAE2016-54110.

[36] de Andrés AD, Guanche R, Meneses L, Vidal C, Losada IJ. Factors that influence array layout on wave energy farms. Ocean Engineering 2014;82:32-41. https://doi.org/10.1016/j.oceaneng.2014.02.027. 
[37] O’Connor M, Lewis T, Dalton G. Techno-economic performance of the Pelamis P1 and Wavestar at different ratings and various locations in Europe. Renewable Energy 2013;50:889-900. https://doi.org/10.1016/j.renene.2012.08.009.

[38] Beels C, Troch P, Kofoed JP, Frigaard P, Vindahl Kringelum J, Carsten Kromann P, et al. A methodology for production and cost assessment of a farm of wave energy converters. Renewable Energy 2011;36:3402-16. https://doi.org/10.1016/j.renene.2011.05.019.

[39] Izquierdo-Pérez J, Brentan BM, Izquierdo J, Clausen N-E, Pegalajar-Jurado A, Ebsen N. Layout Optimization Process to Minimize the Cost of Energy of an Offshore Floating Hybrid Wind-Wave Farm. Processes 2020;8:139. https://doi.org/10.3390/pr8020139.

[40] Carpintero Moreno E, Stansby P. The 6-float wave energy converter M4: Ocean basin tests giving capture width, response and energy yield for several sites. Renewable and Sustainable Energy Reviews 2019;104:307-18. https://doi.org/10.1016/j.rser.2019.01.033.

[41] Chatzigiannakou MA, Dolguntseva I, Leijon M. Offshore Deployments of Wave Energy Converters by Seabased Industry AB. Journal of Marine Science and Engineering 2017;5:15. https://doi.org/10.3390/jmse5020015.

[42] Thomsen JB, Ferri F, Kofoed JP, Black K. Cost Optimization of Mooring Solutions for Large Floating Wave Energy Converters. Energies 2018;11:159. https://doi.org/10.3390/en11010159.

[43] Teillant B, Costello R, Weber J, Ringwood J. Productivity and economic assessment of wave energy projects through operational simulations. Renewable Energy 2012;48:220-30. https://doi.org/10.1016/j.renene.2012.05.001.

[44] Flocard F, Ierodiaconou D, Coghlan IR. Multi-criteria evaluation of wave energy projects on the south-east Australian coast. Renewable Energy 2016;99:80-94. https://doi.org/10.1016/j.renene.2016.06.036.

[45] Bonnard C-H, Blavette A, Bourguet S, Charmetant A. Modeling of a wave farm export cable for electro-thermal sizing studies. Renewable Energy 2020;147:2387-98. https://doi.org/10.1016/j.renene.2019.09.135.

[46] Behrens S, Hayward J, Hemer M, Osman P. Assessing the wave energy converter potential for Australian coastal regions. Renewable Energy 2012;43:210-7. https://doi.org/10.1016/j.renene.2011.11.031.

[47] Dunnett D, Wallace JS. Electricity generation from wave power in Canada. Renewable Energy 2009;34:179-95. https://doi.org/10.1016/j.renene.2008.04.034.

[48] Monds JR. Multicriteria Decision Analysis for Wave Power Technology in Canada. J Energy Resour Technol 2013;136:021201-021201. https://doi.org/10.1115/1.4025408.

[49] Myhr A, Bjerkseter C, Ågotnes A, Nygaard TA. Levelised cost of energy for offshore floating wind turbines in a life cycle perspective. Renewable Energy 2014;66:714-28. https://doi.org/10.1016/j.renene.2014.01.017.

[50] Sheng W, Alcorn R, Lewis T. Physical modelling of wave energy converters. Ocean Engineering 2014;84:29-36. https://doi.org/10.1016/j.oceaneng.2014.03.019.

[51] Wavepiston n.d. http://www.wavepiston.dk/ (accessed February 11, 2020). 
[52] Wavepiston A/S. Wavepiston - Next Generation Wave Power. Hanstholm: ForskEL; 2019.

[53] Schallenberg-Rodríguez J, Del Rio-Gamero B, Melian-Martel N, Lis Alecio T, González Herrera J. Energy supply of a large size desalination plant using wave energy. Practical case: North of Gran Canaria. Applied Energy 2020;278:115681. https://doi.org/10.1016/j.apenergy.2020.115681.

[54] Behrens S, Hayward JA, Woodman SC, Hemer MA, Ayre M. Wave energy for Australia's National Electricity Market. Renewable Energy 2015;81:685-93. https://doi.org/10.1016/j.renene.2015.03.076.

[55] Morim J, Cartwright N, Hemer M, Etemad-Shahidi A, Strauss D. Inter- and intra-annual variability of potential power production from wave energy converters. Energy 2019;169:1224-41. https://doi.org/10.1016/j.energy.2018.12.080.

[56] Aristodemo F, Algieri Ferraro D. Feasibility of WEC installations for domestic and public electrical supplies: A case study off the Calabrian coast. Renewable Energy 2018;121:261-85. https://doi.org/10.1016/j.renene.2018.01.012.

[57] Onea F, Rusu L. Evaluation of Some State-Of-The-Art Wind Technologies in the Nearshore of the Black Sea. Energies 2018;11:2452. https://doi.org/10.3390/en11092452.

[58] Segura E, Morales R, Somolinos JA. Cost Assessment Methodology and Economic Viability of Tidal Energy Projects. Energies 2017;10:1806. https://doi.org/10.3390/en10111806.

[59] Astariz S, Iglesias G. Enhancing Wave Energy Competitiveness through Co-Located Wind and Wave Energy Farms. A Review on the Shadow Effect. Energies 2015;8:7344-66. https://doi.org/10.3390/en8077344.

[60] Castro-Santos L, Martins E, Guedes Soares C. Cost assessment methodology for combined wind and wave floating offshore renewable energy systems. Renewable Energy 2016;97:866-80. https://doi.org/10.1016/j.renene.2016.06.016.

[61] Pecher A, Kofoed JP, editors. Handbook of Ocean Wave Energy. 1st ed. 2017 edition. Springer; 2016.

[62] López I, Andreu J, Ceballos S, Martínez de Alegría I, Kortabarria I. Review of wave energy technologies and the necessary power-equipment. Renewable and Sustainable Energy Reviews 2013;27:413-34. https://doi.org/10.1016/j.rser.2013.07.009.

[63] Weber J. WEC Technology Readiness and Performance Matrix - finding the best research technology development trajectory. 4 th International Conference on Ocean Energy, vol. 17, Dublin, Ireland: 2012.

[64] Parker RPM, Harrison GP, Chick JP. Energy and carbon audit of an offshore wave energy converter. Proceedings of the Institution of Mechanical Engineers, Part A: Journal of Power and Energy 2007;221:1119-30. https://doi.org/10.1243/09576509JPE483.

[65] Dalton GJ, Alcorn R, Lewis T. A 10 year installation program for wave energy in Ireland: A case study sensitivity analysis on financial returns. Renewable Energy 2012;40:80-9. https://doi.org/10.1016/j.renene.2011.09.025. 
919 [66] Astariz S, Iglesias G. Wave energy vs. other energy sources: A reassessment of the 920 economics. International Journal of Green Energy 2016;13:747-55. $921 \quad$ https://doi.org/10.1080/15435075.2014.963587.

922 [67] A HS. Physical Models And Laboratory Techniques In Coastal Engineering. World 923 Scientific; 1993.

924 [68] Wavepiston A/S. Wavepiston MK I test at Nissum Bredning. Denmark: 2013.

925 [69] de Andres A, Medina-Lopez E, Crooks D, Roberts O, Jeffrey H. On the reversed LCOE 926 calculation: Design constraints for wave energy commercialization. International 927 Journal of Marine Energy 2017;18:88-108. https://doi.org/10.1016/j.ijome.2017.03.008. 
Figures

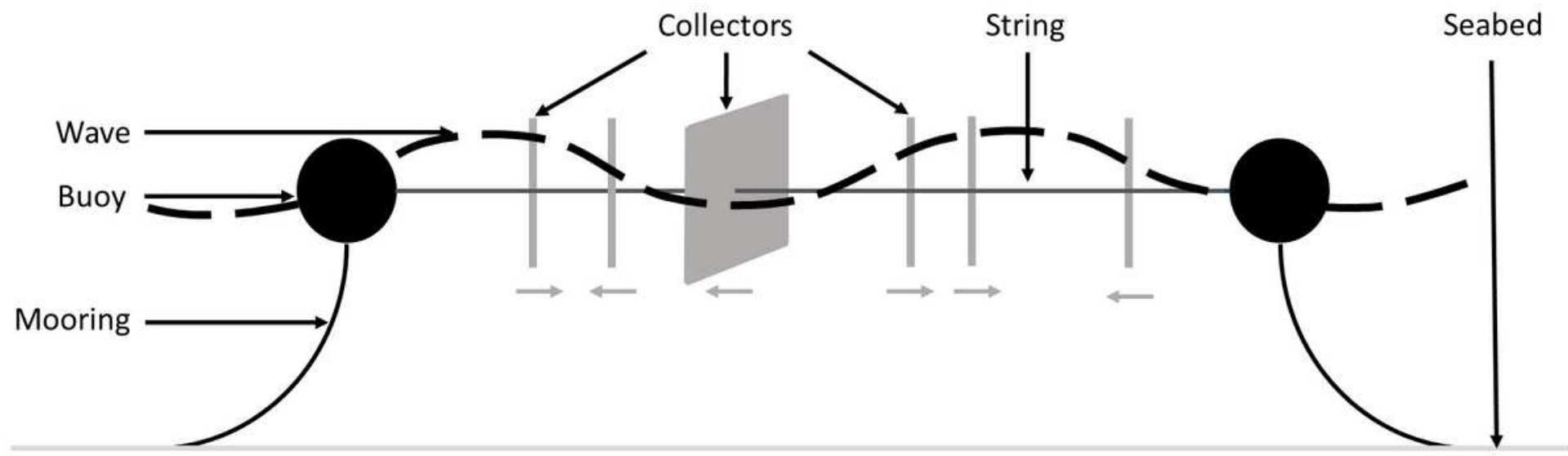

Figure 1

Wavepiston visual description
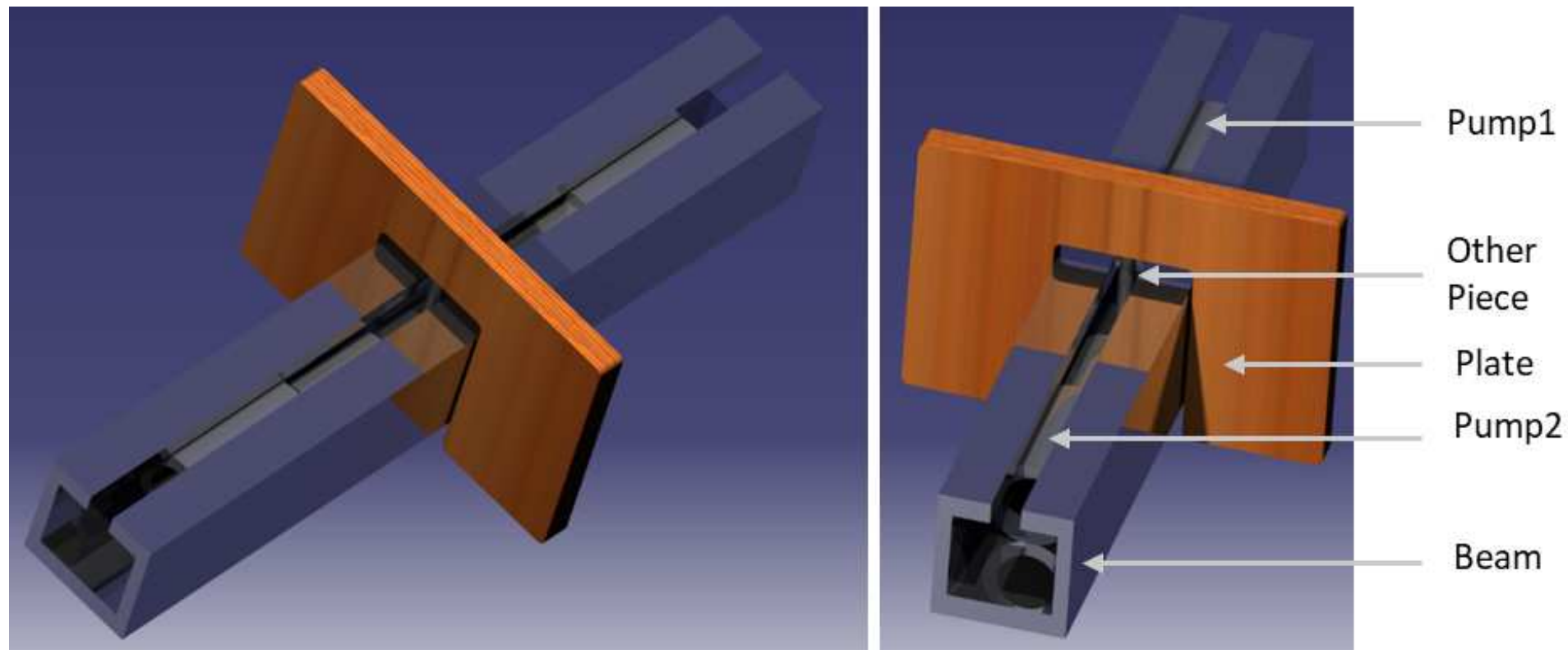

Figure 2

Collector artistic representation 


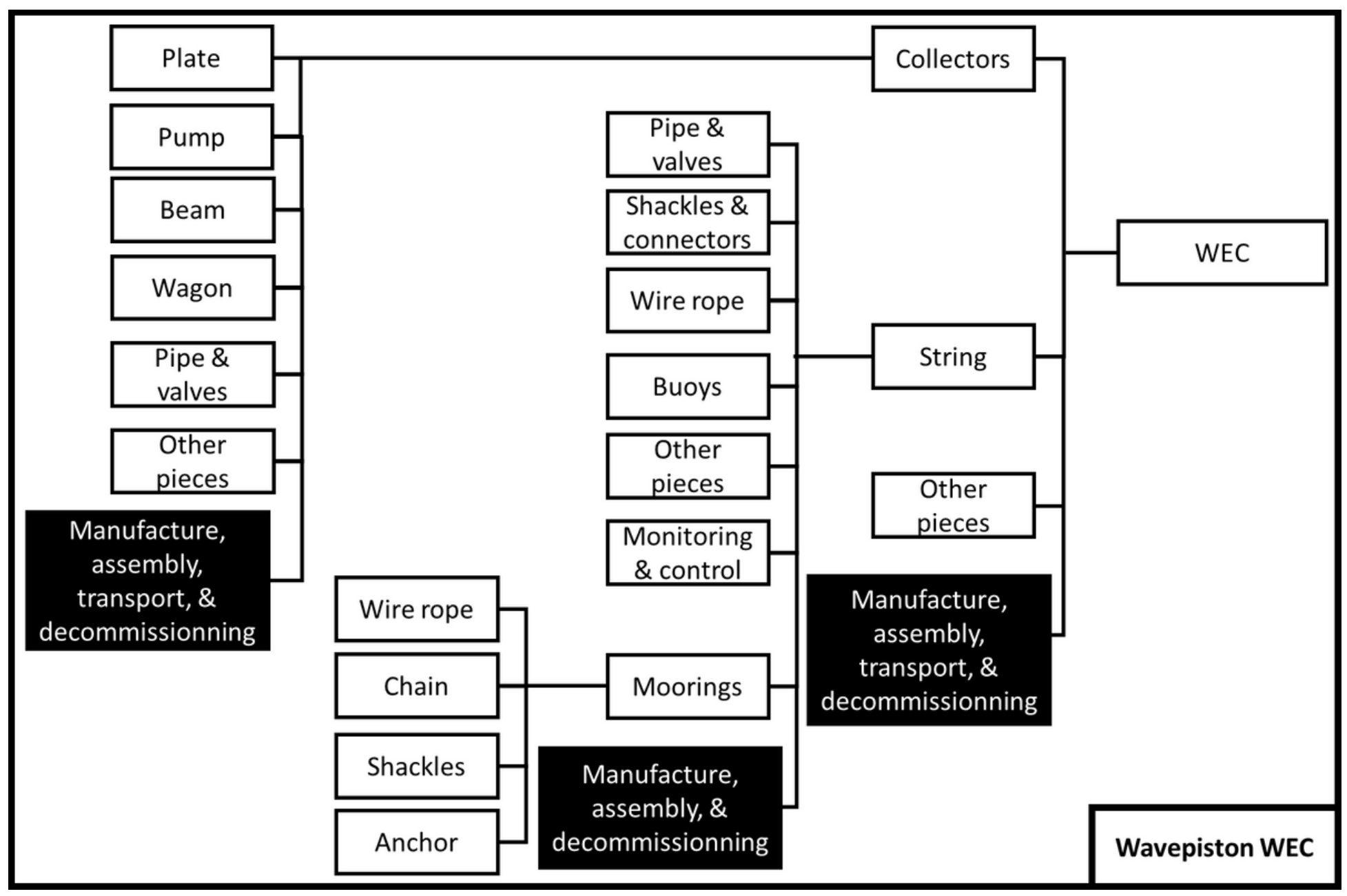

Figure 3

Wavepiston WEC main pieces and components (white cells) and tasks (dark cells) gathering tasks.
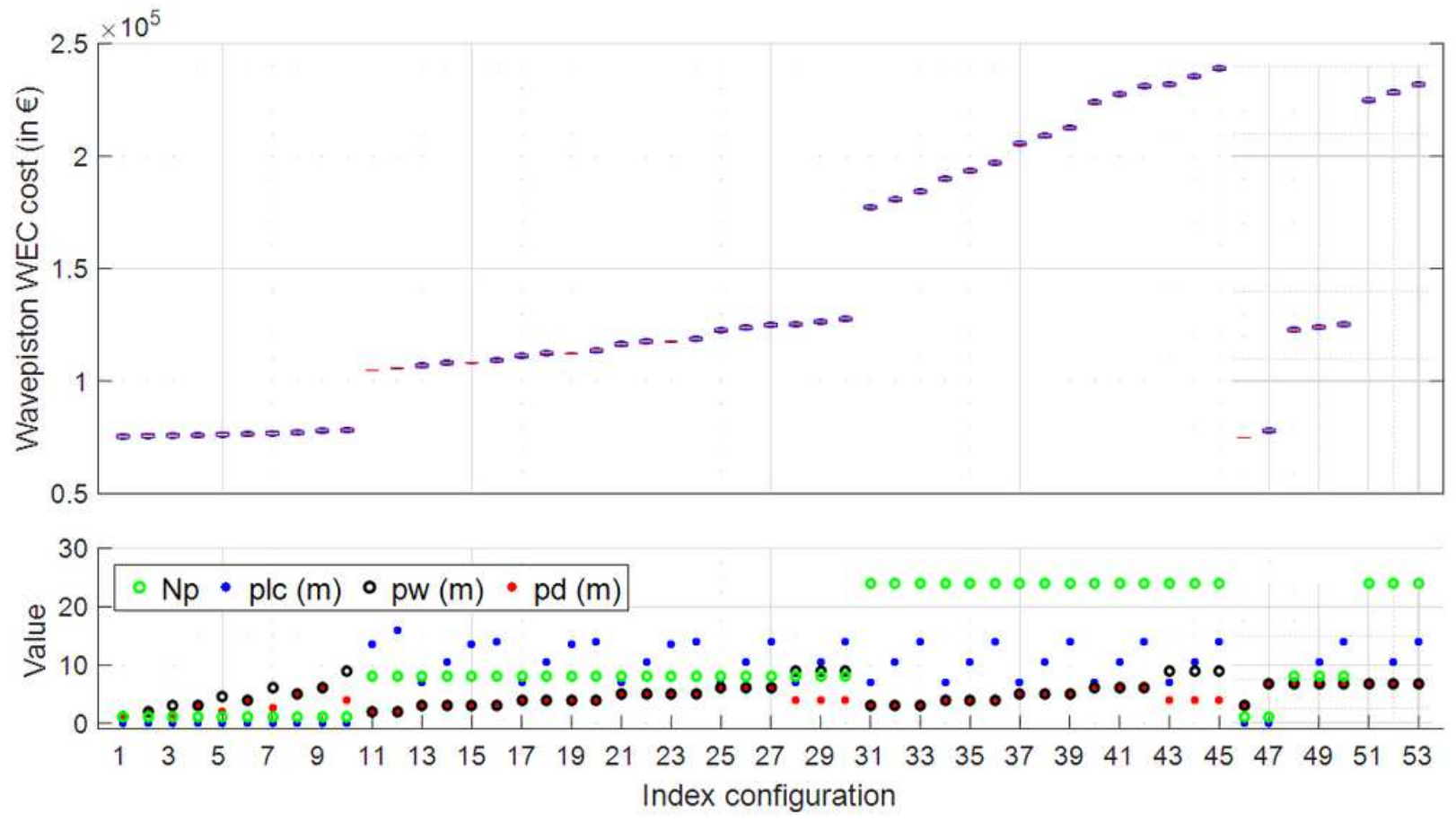
Figure 4

Boxplot that shows the spread of the WEC cost (in €) over the site water depth (see Table 3) clustered per similar configuration of Wavepiston of the other Wavepiston WEC configuration parameters (see Table 2 and Table 3 for parameter definition and values), the grey sections for the elliptical plates

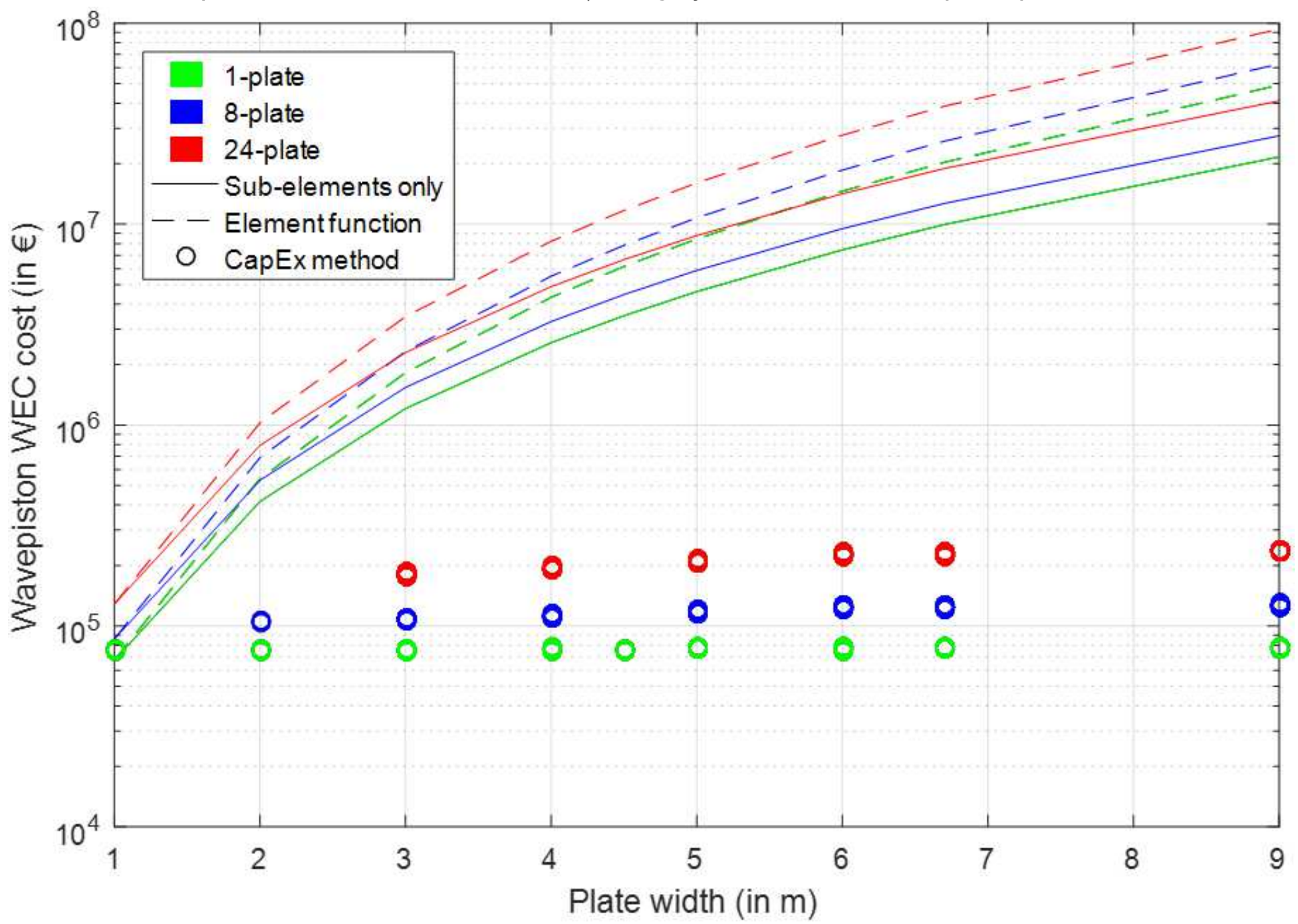

Figure 5

Wavepiston WEC cost (in $€$ ) using the Similitude method over the plate width for the "Sub-element only" and "Element function" weighted scale coefficient results from the CapEx method for the three values of number of plates from the dataset 